\title{
The open sea as the main source of methylmercury in the water column of the Gulf of Lions (Northwestern Mediterranean margin)
}

\author{
Cossa Daniel ${ }^{1,2,}{ }^{*}$, Durrieu De Madron Xavier ${ }^{3}$, Schäfer Jörg ${ }^{4}$, Lanceleur Laurent ${ }^{4}$, \\ Guédron Stéphane ${ }^{2}$, Buscail Roselyne ${ }^{3}$, Thomas Bastien ${ }^{5}$, Castelle Sabine ${ }^{1}$, Naudin Jean-Jacques ${ }^{6}$ \\ ${ }^{1}$ Ifremer, Mediterranean Centre, BP 330, F-83507 La Seyne-sur-Mer, France \\ 2 Université Grenoble Alpes, ISTerre, BP 53, F-38041 Grenoble, France \\ 3 Université de Perpignan, Cnrs-Cefrem, 52, Ave. P. Alduy, F-66860 Perpignan Cedex, France \\ ${ }_{5}^{4}$ Université de Bordeaux, Epoc, F-33615 Pessac, France \\ ${ }^{5}$ Ifremer, Atlantic Centre, BP 21105, F-44311 Nantes Cedex 03, France \\ ${ }^{6}$ Université P. et M. Curie, Lobb, F-66651 Banyuls-sur-Mer, France \\ *Corresponding author : Daniel Cossa, email address : dcossa@ifremer.fr
}

\begin{abstract}
:
Despite the ecologic and economical importance of coastal areas, the neurotoxic bioaccumulable monomethylmercury $(\mathrm{MMHg})$ fluxes within the ocean margins and exchanges with the open sea remain unassessed. The aim of this paper is to address the questions of the abundance, distribution, production and exchanges of methylated mercury species (MeHgT), including $\mathrm{MMHg}$ and dimethylmercury (DMHg), in the waters, atmosphere and sediments of the Northwestern Mediterranean margin including the Rhône River delta, the continental shelf and its slope (Gulf of Lions) and the adjacent open sea (North Gyre).

Concentrations of MeHgT ranged from $<0.02$ to $0.48 \mathrm{pmol} L-1$ with highest values associated with the oxygen-deficient zone of the open sea. The methylated mercury to total mercury proportion (MeHgT/HgT) increased from 2\% to 4\% in the Rhône River to up to 30\% (averaging 18\%) in the North Gyre waters, whereas, within the shelf waters, MeHgT/HgT proportions were the lowest (1-3\%). We calculate that the open sea is the major source of MeHgT for the shelf waters, with an annual flux estimated at $0.68 \pm 0.12 \mathrm{kmol} \mathrm{a-1}$ (i.e., equivalent to $12 \%$ of the $\mathrm{HgT}$ flux). This MeHgT influx is more than 80 times the direct atmospheric deposition or the in situ net production, more than 40 times the estimated "maximum potential" annual efflux from shelf sediment, and more than 7 times that of the continental sources. In the open sea, ratios of $\mathrm{MMHg} / \mathrm{DMHg}$ in waters were always $<1$ and minimum in the oxygen deficient zones of the water column, where MeHg concentrations are maximum. This observation supports the idea that $\mathrm{MMHg}$ could be a degradation product of $\mathrm{DMHg}$ produced from inorganic divalent $\mathrm{Hg}$.
\end{abstract}

Keywords : Mercury, Methylmercury, Ocean margin, Coastal area, Mediterranean 


\section{Introduction}

39 Mercury $(\mathrm{Hg})$ exists in the marine environment as elemental $\mathrm{Hg}\left(\mathrm{Hg}^{0}\right)$ and divalent $\mathrm{Hg}$

40 species, which include various inorganic $\left(\mathrm{Hg}^{\mathrm{II}}\right.$ i) species (e.g., chlorocomplexes) and the two

41 methylated species: monomethylmercury (MMHg) and dimethylmercury (DMHg).

42 Monomethylmercury is a neurotoxin that bioaccumulates in aquatic organisms and

43 biomagnifies through trophic webs (e.g., Jensen and Jernelov, 1969; Clarkson and Magos,

44 2006). However, despite the ecological and economical importance of coastal areas,

45 especially in terms of fish and shellfish production and capture, the distributions, sources and

46 fluxes of methylated $\mathrm{Hg}$ species in the waters of the ocean margins are still poorly explored.

47 Methylated $\mathrm{Hg}$ sources for coastal waters include (i) inputs from upwellings, rivers,

48 groundwaters, atmospheric deposition and waste water point sources, and (ii) in situ $\mathrm{Hg}^{\mathrm{II}}{ }_{\mathrm{i}}$

49 methylation in coastal waters and sediments (Cossa et al., 1996; Fitzgerald et al., 2007). The

50 river-watershed contribution can be large due to direct inputs of $\mathrm{MMHg}$ to coastal waters

51 (Coquery et al., 1997; Choe and Gill, 2003; Balcom et al., 2008 and 2015; Muresan et al.,

52 2008; Guédron et al., 2012; Buck et al., 2015) and continental groundwaters via submarine

53 estuaries (Ganguli et al., 2012). Contribution of the open ocean to the methylated Hg load of

54 oceanic margin waters has also been evidenced: DMHg is conveyed, via upwellings, from

55 ocean interior to surface coastal waters (Conaway et al., 2009). Atmosphere has been reported 
56 as external methylated $\mathrm{Hg}$ sources, but available data are limited (e.g., Weiss-Penzias et al.,

572012 and 2016). In situ Hg methylation has been observed in both coastal sediments (e.g.,

58 Gobeil and Cossa, 1993; Hammerschmidt et al., 2004; Hammerschmidt and Fitzgerald, 2006;

59 Balcom et al., 2008; Hollweg et al., 2009 and 2010; Luengen and Flegal, 2009; Noh et al.,

60 2013) and waters (Mason et al., 1993; Sunderland et al., 2010; Lehnherr et al., 2011; Wang et

61 al., 2012; Lehnherr, 2014; Schartup et al., 2015). Experimental MMHg production from

62 incubation of settling particles ("marine snow") or water strongly suggests that water column

63 methylation may be important worldwide (Monperrus et al., 2007; Ortiz et al., 2015). In

64 summary, numerous internal and external sources of methylated $\mathrm{Hg}$ in coastal waters exist;

65 however, their relative importance is not well established.

66 Pathways of $\mathrm{Hg}$ methylation in both oceanic and coastal waters are still poorly

67 described, despite the oceanographically-consistent measurements of methylated $\mathrm{Hg}$

68 performed for three decades in the waters of the Atlantic Ocean (Mason et al., 1998; Mason

69 and Sullivan, 1999; Bowman et al., 2015), the Pacific Ocean (Mason and Fitzgerald, 1990;

70 Hammerschmidt and Bowman, 2012; Munson et al., 2015), and the Mediterranean Sea (Cossa

71 et al., 1994, 1997 and 2009; Horvat et al., 2003). The highest concentrations of methylated Hg

72 are consistenly found in the oxygen deficient zones (ODZs). The generally significant

73 correlation between methylated $\mathrm{Hg}$ and oxygen consumption (or organic carbon regeneration

74 rates) have been interpreted as the result of net microbiological $\mathrm{Hg}^{\mathrm{II}}{ }_{i}$ methylation at these

75 depths (e.g., Mason and Fitzgerald, 1990; Cossa et al., 2009; Sunderland et al., 2009). The

$76 \mathrm{MMHg} / \mathrm{DMHg}$ molar ratios in the ODZs vary broadly $(0.2$ to $>10)$ depending on location,

77 even in the same oceanic region. Early North Atlantic data suggests that MMHg is a

78 degradation product of DMHg in the water column (Fitzgerald and Mason, 1996; Mason et 
79 al., 1998; Mason and Sullivan, 1999). However, production rate measurements, performed on

80 Arctic waters, found contradictory results (Lehnheer et al., 2011). These authors found that

$81 \mathrm{DMHg}$ production from $\mathrm{Hg}^{\mathrm{II}}{ }_{\mathrm{i}}$ was two orders of magnitude less than $\mathrm{MMHg}$ production, but

82 faster than the rate of DMHg production from MMHg methylation. Consistent with these

83 findings, recent results show that MMHg is the dominant form of methylated Hg in deep

84 waters of the North Atlantic (Bowman et al., 2015). More recently, Jonsson et al. (2016)

85 suggest that MMHg can be methylated on sulfide mineral surfaces, a pathway potentially

86 responsible for much of the DMHg in oceanic waters. In summary, data on MMHg and

87 DMHg distributions in marine waters are still scarce (especially in coastal areas), and,

88 consequently, the methylation mechanism of $\mathrm{Hg}^{\mathrm{II}}{ }_{\mathrm{i}}$ remains uncertain.

89 In the present work, we address questions of abundance, distribution, production and

90 exchanges of methylated $\mathrm{Hg}$ in the waters of the Northwestern Mediterranean margin

91 including the Rhône River delta, the continental shelf and its slope (Gulf of Lions), the

92 continental rise and the adjacent open sea (North Gyre) (Fig. 1). The objective is to assess the

93 relative importance of internal and external sources of methylated $\mathrm{Hg}$ in the context of marine

94 Hg cycle. For this, we have (i) monitored atmospheric deposition and riverine inputs of total

95 methylated $\mathrm{Hg}(\mathrm{MeHgT}=\mathrm{MMHg}+\mathrm{DMHg})$, (ii) studied the MeHg distribution within the

96 Rhône River plume, the freshwater-sea water mixing zone, the continental shelf-slope-rise

97 system, and the adjacent open sea, and (iii) estimated the $\mathrm{MeHg}$ exchanges across various

98 interfaces, including water/sediment and coastal/off-shore water interface. Additional data of

99 total $\mathrm{Hg}(\mathrm{HgT}=$ all the $\mathrm{Hg}$ species $)$ were also collected in order to estimate the importance of

$100 \mathrm{MeHg}$ fraction. 
103 The Northwestern Mediterranean is characterized by the presence of a large continental shelf 104 and the associated slope, both constituting the Gulf of Lions (Fig. 1). The water circulation in

105 the Gulf of Lions is influenced in the South by the Northern Current, which is a part of a 106 current system going from the Tyrrhenian Sea up to the Alboran Sea (Millot and Tapier107 Letage, 2005). This Northern Current flows as a major vein along the upper part of the 108 continental slope intruding onto the shelf (Fig. 1). The North Gyre and Gulf of Lions have 109 contrasting hydrological and biological properties. The North Gyre is a typical oligotrophic

110 open Mediterranean environment experiencing strong winter mixing of the surface and

111 intermediate water masses, whereas the Gulf of Lions constitutes one of the few mesotrophic 112 coastal regions within the Mediterranean Sea (Morel and André, 1991) largely influenced by 113 the Rhône River freshwater inputs.

114 The Gulf of Lions receives riverine inputs mainly from the Rhône River. The Rhône

115 River is the major freshwater input to the western Mediterranean and its waters undergo three 116 main processes before being diluted in the Gulf of Lions waters. First, freshwater is rapidly

117 mixed with seawater within the few kilometers between Barcarin and the prodelta area (Fig.

118 1) (Elbaz-Poulichet et al., 1996). Secondly, the Rhône River plume is driven on the shelf by

119 changeable continental winds (the northerly Mistral, southwesterly Tramontane and

120 southeasterly-easterly Marin) and the cyclonic Northern Current (Fig. S1) (Naudin et al., 121 1997). The plume is periodically broken due to wind direction changes, producing "Low

122 Salinity Water" lenses drifting on the shelf Naudin et al. (1997). Thirdly, below the Rhône

123 River plume, the dense riverine particles settle abruptly, generating large sediment

124 accumulation in the prodelta area up to several tens of centimeters per year in the proximal 
125 delta ( $20 \mathrm{~m})$ according to Charmasson et al. (1998), Radakovitch et al. (1999), Maillet et al.

126 (2006) and Cathalot et al. (2010). Finer riverine material is exported farther on the Gulf of

127 Lions shelf, undergoing a westward net transport through sedimentation/resuspension

128 processes generated by infrequent easterly wind storm events (Durrieu de Madron et al., 2008;

129 Ulses et al., 2008; Guizien, 2009; Marion et al., 2010; Bourrin et al., 2015).

\section{Material and methods}

132 To summarize the nomenclature used in the following text, $\mathrm{X}_{\mathrm{UNF}}, \mathrm{X}_{\mathrm{F}}$ and $\mathrm{X}_{\mathrm{P}}$ refer to unfiltered,

133 dissolved $(<0.45 \mu \mathrm{m})$ and particulate, respectively (with $\mathrm{X}$ being a $\mathrm{Hg}$ species). Detailed

134 protocols of the sampling and analytical techniques are given in SI 1. Sampling and water

135 sample treatments were performed using ultraclean protocols, including acid cleaning of the

136 plastic ware, and the use of plastic gloves and high purity grade reagents (e.g., SUPRAPUR HCl

137 from Merck ${ }^{\circledR}$, ULTREX $\mathrm{HNO}_{3}$ from J.T. Baker ${ }^{\circledR}$ ).

\section{3.1. Sampling}

139 Sampling cruise identifications, locations and dates are summarized in Table S1.

140 Atmospheric deposition. Thirteen rain events were collected between April 2009 and January

1412010 at a coastal site (La Seyne-sur-Mer, $43^{\circ} .06 .350^{\prime}$ N; $5^{\circ} 53.117^{\prime}$ E, Fig.1), located at the

142 eastern end of the Gulf of Lions. The unfiltered samples were collected in Teflon (FEP)

143 bottles and acidified $(0.4 \% \mathrm{v} / \mathrm{v} \mathrm{HCl})$ immediately after the water collection. The rain-

144 collecting device (PP040, MTX ${ }^{\circledR}$ ) was located $15 \mathrm{~m}$ above sea level. Details of the sampling

145 are given by Castelle (2010). At the same site, 28 aerosol samples were collected on cellulose

146 acetate membranes $(0.22 \mu \mathrm{m})$ from July 2009 to March 2010. Each sample represents one 
147 week of pumping at a pumping rate of $14 \mathrm{~L} \mathrm{~min}^{-1}$. Total gaseous $\mathrm{Hg}$ concentrations in the

148 atmosphere were monitored at the same time (Marusczak et al., 2015).

149 Rhône River monitoring. Rhône River Hg monitoring was performed over two monitoring 150 periods at Arles (Sta. SoRA, Fig. 1): (i) a period of low river waters from March, 2009 to June, 1512010 , with only one rather weak flood event $\left(\sim 3000 \mathrm{~m}^{3} \mathrm{~s}^{-1}\right.$ on December the $\left.2^{\text {nd }}\right)$, and (ii) 152 during the flooding period of October-November 2008 (up to $3580 \mathrm{~m}^{3} \mathrm{~s}^{-1}$ ). Surface freshwater 153 samples were collected twice a month at Station SORA in Arles (Fig. 1) by pumping through

154 polyethylene tubing using an all-Teflon (PFA) double-bellows pump (10-LPM, ASTI ${ }^{\circledR}$ ). 155 Samples were collected in Teflon (FEP) bottles then filtered through hydrophilic Teflon 156 membranes (LCR, Millipore ${ }^{\circledR}$ ) with a porosity of $0.45 \mu \mathrm{m}$. Membranes were stored at $-18^{\circ} \mathrm{C}$ 157 in polycarbonate Petri dishes and the filtrates were acidified $(0.4 \% \mathrm{v} / \mathrm{v} \mathrm{HCl})$ and stored in 158 Teflon (FEP) bottles.

159 Rhône delta mixing zone. Brackish surface waters were sampled on 16 and 17 October 2008 160 from a rubber boat between Barcarin (Rhône River) and the sea (Fig.1); the locations of the 161 stations are indicated on Table S2a. The samples were collected directly into Teflon (FEP)

162 bottles. Samples were then filtered and stored as described in the previous section.

163 BIOPRHOFI cruise. During the BIOPROHFI cruise $\left(14^{\text {th }}-27^{\text {th }}\right.$ May 2006), two types of waters

164 were sampled: (i) the productive shelf waters and (ii) the mesotrophic slope waters. In the first 165 type, two Low Salinity Waters, originating from the Rhône River plume, were successively 166 tracked using a Lagrangian sampling protocol: lens “ 1 ” between May $14^{\text {th }}$ and $18^{\text {th }}$, 167 corresponding to stations S1 to S68 and lens " 2 " between the $19^{\text {th }}$ and $26^{\text {th }}$, corresponding to 168 stations S88 to S220 (Fig. S2). In the lenses, the 0-50 m layer was sampled by pumping with 169 the all-Teflon pneumatic pump (10-2PM, ASTI $\left.{ }^{\circledR}\right)$ and through polyethylene tubing, directly 
170 into a class 100 on-board clean laboratory; the water depth varied between 60 and $100 \mathrm{~m}$

171 during the drifting. Two deep casts $(0-900 \mathrm{~m})$ were performed on May the $26^{\text {th }}$ at the slope

172 foot (Stas. S221 and S230, Fig. S2); their coordinates are given in Table S2a.

173 CASCADE cruise. During the CASCADE cruise $\left(1^{\text {st }}-23^{\text {th }}\right.$ March 2011), water was collected (i)

174 on the inner shelf from the Rhône prodelta to the south-western end (Stas. A to D), (ii) at the

175 head of Cap de Creus canyon (Sta. E), and (iii) thirteen deep casts on the shelf edge (Stas. L-

17601 and M-12), the slope foot (Stas. L-03 and M-10) and within the North Gyre (Stas. Antarès,

177 S2400, L-05-08-10-12 and M-03-05-08) (Fig. 1). Two to twelve water depths were sampled

178 for each cast depending on the height of the water column (Fig. 1 and Table S2). Sediment

179 cores were collected along the Gulf of Lions shelf, at the head of the Cap de Creus canyon

180 and in the abyssal plain in the North Gyre area during the CASCADE cruise (Table S2b). A

181 multicore sampler (Oktopus GmbH Multiple corer with 8 tubes of $100 \mathrm{~mm}$ diameter) allowing

182 the sampling of the undisturbed benthic interface (Barnett et al., 1984) was used.

\section{3.2. Sample treatment}

184 Water and particles. The samples from the 0-50 m layer of the shelf waters during the

185 BIOPRHOFI cruise were filtered through polycarbonate membranes $\left(0.45 \mu \mathrm{m}\right.$, Nuclepore $\left.{ }^{\circledR}\right)$.

186 Filtrate was collected in Teflon (FEP) bottles and acidified with $\mathrm{HCl}(0.4 \%, \mathrm{v} / \mathrm{v})$. The

187 collection of particles from the Low Salinity Waters, for subsequent MMHg, particulate carbon

188 and phosphorus, and pigments determinations, was performed using in-line filtration through

189 pre-heated glass fiber filters $\left(\mathrm{GF} / \mathrm{G}, \mathrm{Whatman}^{\circledR}\right)$. Deep-water samples $(>50 \mathrm{~m})$ were collected

190 during the BIOPRHOFI and CASCADE cruises by rosette-mounted 5L bottles (1010X-Niskin,

191 General Oceanics ${ }^{\circledR}$ ) equipped with a CTD probe. These samples were not filtered and were

192 analyzed only for $\mathrm{HgT}_{\mathrm{UNF}}$ and $\mathrm{MeHg} \mathrm{T}_{\mathrm{UNF}}$. Total $\mathrm{Hg}$ was determined on board, whereas 
$193 \mathrm{MMHg}$ and MeHgT analyses were performed in the laboratory within 2 months after the

194 cruise on the acidified samples stored in the dark at $+4^{\circ} \mathrm{C}$ in a double wrapping of polyethylene 195 bags.

196 Sediment pore water: The sediment pore water was extracted, from below the sediment

197 surface $(-1 \mathrm{~cm})$, using Milli-Q (Millipore ${ }^{\circledR}$ ) water-rinsed microporous polymer tube samplers

198 (Rhizon SMS, Rhizosphere Research Products ${ }^{\circledR}$ ) attached to an acid washed all-polypropylene

199 syringe (Guédron et al., 2012).

\section{3.3. Chemical analyses}

201 Total mercury. Total Hg, in filtered and unfiltered samples, was measured on board within a

202 few minutes of sampling. The release of $\mathrm{Hg}$ from its ligands was achieved by addition of a

$203 \mathrm{BrCl}$ solution. This technique is known as the Environmental Protection Agency from the

204 United States of America standard method $N^{\circ} 1631$

205 (www.epa.gov/sites/production/files/2015-08/documents/method_1631e_2002.pdf). The

206 detection limit ( $\mathrm{DL}=3$ times the standard deviation of the blank) was $0.1 \mathrm{pmol} \mathrm{L} \mathrm{L}^{-1}$ and the

207 reproducibility varied according to the concentration level between 5 and $15 \%$ (Cossa et al.

208 2003). The accuracy of HgT measurements was tested using the ORMS-3 water sample,

209 which is a certified reference material (CRM) from the National Research Council of Canada.

210 Our measurements were always within the confidence limits given for the CRM (12.6 \pm 1.1

211 pg mL ${ }^{-1}$; http://inms-ienm.nrc-cnrc.gc.ca/calserv/crm_files_f/ORMS-3_f.pdf).

212 Methylated $\mathrm{Hg}$ species. Total methylated $\mathrm{Hg}$ and $\mathrm{MMHg}$ were measured on filtered and

213 unfiltered samples and DMHg was calculated as the difference between MeHgTuNF and

214 MMHgunf. Since DMHg is converted into MMHg at low pH (Mason, 1991; Black et al.,

215 2009a) MeHgT was determined on acidified samples. Monomethyl Hg was determined after 
216 bubbling samples for 40 min with argon in order to remove DMHg before acidification. Total

217 methylated Hg and MMHg were determined as volatile MMHg hydride by purge and cryo-

218 trapping gas chromatography and detected as elemental $\mathrm{Hg}$ vapor by atomic fluorescence

219 spectrometry according to Stoichev et al. (2004). The mercury hydrides (from MMHg and

$220 \mathrm{Hg}^{\mathrm{II}}$ ) were formed with $\mathrm{NaBH}_{4}$, sparged from the sample with helium, concentrated and then

221 separated by cryogenic chromatography before detection. During this set of analyses, the low

222 blank $(<0.01 \mathrm{pmol})$ and its reproducibility (2\%) allowed and limits of quantification (LQ) as

223 low as 0.005 and 0.015 to $0.075 \mathrm{pmol} \mathrm{L}^{-1}$, respectively. The analytical reproducibility varied

224 with time between 6 and $15 \%$.

$225 \mathrm{MeHgT}_{\mathrm{P}}$ was determined by atomic fluorescence spectrometry after acid extraction,

226 ethylation and chromatographic separation according to Liang et al. (1994). The analytical

227 performances were established by analyzing a Certified Reference Material from the

228 International Atomic Energy Agency (IAEA-142, Horvat et al., 1997). The reproducibility

229 was $10 \%$ and the DL $20 \mathrm{pmol} \mathrm{g}^{-1}$; recovery varied from 80 to $100 \%$.

230 Isotopic incubations. Incubation experiments were performed onboard immediately after

231 sampling using a ${ }^{199} \mathrm{Hg}^{\mathrm{II}}$ stable isotope spike to study $\mathrm{Hg}$ methylation potentials in

232 Mediterranean bottom water samples as described for tropical lake water incubations in

233 Huguet et al. (2010). These experiments aimed at simulating the temporal resuspension of

234 reducing sediments in oxic bottom water and evaluating their impact on gross methylation

235 compared to that in bottom water without sediment resuspension. For this, we determined

236 gross methylation in (a) unfiltered bottom water and (b) slurries of surface sediment

237 resuspended in unfiltered bottom water as follows: 
239 were transferred into acid-cleaned $125 \mathrm{~mL}$ Teflon (FEP) bottles, spiked with ${ }^{199} \mathrm{Hg}^{\mathrm{II}}$ (Oak

240 Ridge, $92 \%$ purity) to a nominal concentration of $1000 \mathrm{ng}{ }^{199} \mathrm{Hg}^{\mathrm{II}} \mathrm{L}^{-1}$ and incubated at

241 constant temperature $\left(12{ }^{\circ} \mathrm{C}\right)$ in the dark for 48,96 and 192 hours $(\mathrm{n}=2$ for each time;

242 manual shaking twice per day). Aliquots $(n=2)$ of unfiltered bottom water were spiked

243 and methylation was immediately stopped for control. After each incubation time,

244 methylation was stopped by adding $1 \mathrm{~mL}$ of $12 \mathrm{M} \mathrm{HCl}$ (INSTRA analyzed, J.T. Baker ${ }^{\circledR}$ )

245 and the bottles were stored in double sealed polypropylene bags at $4{ }^{\circ} \mathrm{C}$ and in the dark

246 until analysis for isotopic composition of the different $\mathrm{Hg}$ species.

- (b) Surface sediments from the shelf at Stations A to D were added to $100 \mathrm{ml}$ of

248 unfiltered bottom water from the respective site to obtain a nominal suspended particle

249 concentration of $100 \mathrm{mg} \mathrm{L}^{-1}$; three aliquots per site) in acid-cleaned $125 \mathrm{~mL}$ Teflon (FEP)

250 bottles, to simulate resuspension events.

251 The slurries were then spiked with ${ }^{199} \mathrm{Hg}^{\mathrm{II}}$ (Oak Ridge, $92 \%$ purity) to a nominal

252 concentration of $25 \mathrm{ng}$ of $\mathrm{Hg}$ per gram of sediment slurry, including water and sediment,

253 and incubated at constant temperature $\left(12{ }^{\circ} \mathrm{C}\right)$ in the dark for 192 hours. Incubation was

254 stopped by freezing $\left(-20^{\circ} \mathrm{C}\right)$. The samples were stored frozen, freeze-dried and stored

255 cool in the dark until extraction with $\mathrm{HNO}_{3}\left(6 \mathrm{M}\right.$, UltREX, J.T. Baker $\left.{ }^{\circledR}\right)$ and analysis. The

256 applied protocol including derivation (propylation with $\mathrm{NaBPr}_{4}$ ), extraction and the

257 analytical setup, i.e. gas chromatography (Focus GC, Thermo Fischer Scientific ${ }^{\circledR}$ )

258 coupled to ICP-MS (X7, Thermo Fischer Scientific $\left.{ }^{\circledR}\right)$ using a thermostatic interface is

259 based on the methods described in detail elsewhere (Monperrus, 2004). The difference

260 between the $\mathrm{MM}^{199} \mathrm{Hg}$ measured and the $\mathrm{MM}^{199} \mathrm{Hg}$ naturally present (calculated from the 
261 amount of $\mathrm{MM}^{200} \mathrm{Hg}$ measured) represents the $\mathrm{MM}^{199} \mathrm{Hg}$ produced during the incubation

262 of the ${ }^{199} \mathrm{Hg}^{\mathrm{II}}$ added. Methylation potential was estimated by dividing the amount of

$263 \mathrm{MM}^{199} \mathrm{Hg}$ formed by the amount of ${ }^{199} \mathrm{Hg}^{\mathrm{II}}$ recovered after the respective incubation

264 periods, as described by Monperrus et al. (2007).

265 Particulate organic carbon, phosphorus and pigments. Particulate organic carbon

266 concentrations were measured according to Hedges and Stem (1984) with a Shimadzu ${ }^{\circledR}$

267 analyzer (TOC-5000 Series). Soluble reactive phosphorus (SRP) was determined in

268 seawater with an auto-analyzer using the standard molybdate blue method (Murphy and

269 Riley, 1962) as detailed in the protocol by Aminot and Kérouel (2007). Particulate

270 phosphorus $\left(\mathrm{P}_{\mathrm{P}}\right)$ determination used the same colorimetric method but after magnesium

271 nitrate oxidation (Ormaza-Gonzalez and Statham, 1996). Chlorophyll pigments were

272 determined following the standard method by Strickland and Parsons (1972).

\section{RESUlts}

\section{4.1. Atmospheric deposition}

276 Total $\mathrm{Hg}$ concentrations in unfiltered rain water varied from 10 to $80 \mathrm{pmol} \mathrm{L}^{-1}$, with a mean of

$27731 \pm 22 \mathrm{pmol} \mathrm{L}^{-1}(\mathrm{n}=13)$, whereas MeHgT concentrations varied from 0.10 to $1.25 \mathrm{pmol} \mathrm{L}^{-1}$,

278 with a mean of $0.59 \pm 0.33 \mathrm{pmol} \mathrm{L}^{-1}(\mathrm{n}=13)$, i.e., $\sim 2 \%$ of the HgT. These ranges are similar

279 to those published for other coastal areas of the Northern Hemisphere (e.g., Hammerschmidt

280 et al., 2007; Marusczak et al., 2011; Weiss-Penzias et al., 2012). Methylated Hg

281 concentrations in the 28 aerosol samples were undetectable due to the too-small amount of

282 sample collected on the membrane. 


\subsection{Rhône River and its plume}

284 During the low flow period $\mathrm{MeHg}_{\mathrm{F}}$ and $\mathrm{MeHg}_{\mathrm{P}}$ concentrations varied in the picomolar range

285 (Table 1), MeHg being predominantly (90\%) associated with suspended particles. The mean

286 methylated $\mathrm{Hg}$ fractions $(\mathrm{MeHg} / \mathrm{HgT})$ were 4 and $2 \%$ as dissolved and particulate,

287 respectively.

The variations of dissolved $\mathrm{MeHg}$ concentrations $\left(\mathrm{MeHgT}_{\mathrm{F}}\right)$ during the mixing of

289 Rhône freshwater with Gulf of Lions saltwater, between Barcarin ferry and the prodelta area,

290 are illustrated in Figure 2a. Concentrations of $\mathrm{MeHgT}_{\mathrm{F}}$ varied from 0.02 to $0.14 \mathrm{pmol} \mathrm{L}^{-1}$ and

291 the distribution follows a conservating mixing line $\left(\mathrm{R}^{2}=0.75, p<0.01\right)$ with higher

292 concentrations in the freshwater and lower concentrations in the seawater end-member (Fig.

293 2a), similarly to observations of Noh et al. (2013) in the Mekong River delta.

294 At the bottom of the Low Salinity Waters lenses ( $50 \mathrm{~m})$, salinity ranged from 38.2 to

29538.4 , which are typical values for waters of the Northern Current. The lowest salinity in the

296 Low Salinity Waters (32.5) at surface indicates a $20 \%$ dilution of marine waters with the

297 Rhône River waters. The $\mathrm{MeHgT}_{\mathrm{F}}$ concentrations were in the femtomolar range, with 35 \%

298 of values lower than the LQ (i.e., $<0.015 \mathrm{pmol} \mathrm{L}^{-1}$ ) and maximum concentration of 0.069

299 pmol L ${ }^{-1}$ (Table 2). $\mathrm{MeHgT}_{\mathrm{F}}$ fraction varies from $<0.3$ to $5.5 \%$, averaging $1.5 \pm 1.0 \%$ of the

$300 \mathrm{HgT}_{\mathrm{F}}$. The time series of $\mathrm{MeHgT}_{\mathrm{F}}$ concentrations in the Low Salinity Waters varied little with

301 depth (Fig. 3). Interesting to note is that high $\mathrm{MeHgT}_{\mathrm{F}}$ concentrations occurred at the highest

302 salinities, suggesting a marine MeHg source (Fig. 2b).

\section{4.3. Vertical profiles along shelf and slope}


304 On the shelf, average MeHgT $\mathrm{UNF}_{\mathrm{N}}$ concentrations were $0.026 \pm 0.024 \mathrm{pmol} \mathrm{L}^{-1}(\mathrm{n}=40)($ Table

3053 and Fig. 4a). The $\mathrm{MeHgT}_{\mathrm{UNF}} / \mathrm{HgT}_{\mathrm{UNF}}$ ratios averaged roughly $2 \%$, ranging from 0.1 to 6.3

$306 \%$ (Table 3).

307 Tables 2 and 3 summarize the results obtained for the "slope foot" (900-1800m bottom 308 depth) water column in May 2006 (Sta. S-230, BIOPRHOFI cruise) and in March 2011 (Sta. L-

30903 and M-10, CASCADE cruise). Concentrations of MeHgTunF ranged from 0.02 to 0.38 pmol

$310 \mathrm{~L}^{-1}$, averaging $18 \%$ of the $\mathrm{HgT}_{\mathrm{UNF}}$ (Tables 2 and 3). MeHgT UNF were significantly higher

311 below than above $100 \mathrm{~m}(p<0.05)$, suggesting removal and/or photodegradation for

312 methylated $\mathrm{Hg}$ in upper layer and regeneration and/or production below (Fig. 4b, Table 2).

\section{4.4. Deep profiles in the North Gyre}

314 Summary statistics for $\mathrm{Hg}$ species concentrations are given in table 3. Methylated $\mathrm{Hg}$

315 concentrations in unfiltered samples ranged from $0.020 \mathrm{pmol} \mathrm{L}^{-1}$ at surface at Sta. S2400 to

$3160.478 \mathrm{pmol} \mathrm{L}^{-1}$ at $500 \mathrm{~m}$ at Sta. L-10 (Fig. 5a). Expressed as a fraction of the HgT, MeHgT

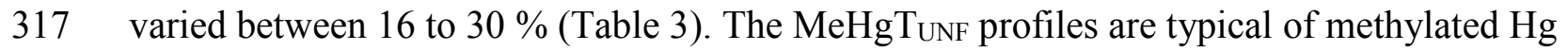

318 vertical distribution in open ocean (e.g., Fitzgerald et al., 2007; Cossa et al., 2011; Mason et

319 al., 2012), i.e., very low concentrations at surface increasing with depth (Fig. 5a). At five

320 stations, $\mathrm{MMHg}$ was determined in addition to $\mathrm{MeHgT}$, allowing calculation of $\mathrm{DMHg}$

321 concentrations by difference. Results indicate $\mathrm{MMHg} / \mathrm{DMHg}$ ratios always lower $<1$, varying

322 from 0.04 to 0.81 (Fig. 5b).

\section{4.5. Sediment pore waters}

324 Concentrations of $\mathrm{MeHgT}_{\mathrm{F}}$ in pore waters extracted from surface sediments $(0-2 \mathrm{~cm})$ were

325 clearly higher (4-20 times) than in the overlaying waters and in the corresponding lower-water 
326 column (Tables 3 and 4). Moreover, concentrations in sediment pore waters of North Gyre

327 were one order of magnitude higher than the shelf pore waters, ranging from 2.05 to 2.18

$328 \mathrm{pmol} \mathrm{L} \mathrm{L}^{-1}$ and from 0.07 to $0.68 \mathrm{pmol} \mathrm{L}^{-1}$, respectively (Table 4).

\section{4.6. Ex situ methylation experiments}

330 Concentrations of inorganic $\mathrm{Hg}$ in sediments ranged from $0.432 \pm 0.030 \mathrm{nmol} \mathrm{g}^{-1}$ (Sta. B) to

$3310.598 \pm 0.122 \mathrm{nmol} \mathrm{g}^{-1}$ (Sta. A), with a mean of $0.519 \pm 0.084 \mathrm{nmol} \mathrm{g}^{-1}$. The results of the

332 sediment incubation experiments showed clearly modified $\mathrm{MM}^{199} \mathrm{Hg} / \mathrm{MM}^{200} \mathrm{Hg}$ ratios

333 compared to both natural values $(0.72 \pm 0.005 ; \mathrm{n}=3)$ and isotope ratios observed in control

334 samples where incubation was stopped immediately after the spike $(0.76 \pm 0.023 ; \mathrm{n}=3$; Fig.

335 6a). The three replicate incubations performed for each site generally provided reproducible

336 results, revealing clear differences between the stations. The sediment samples from Sta. A

$337\left(\mathrm{MM}^{199} \mathrm{Hg} / \mathrm{MM}^{200} \mathrm{Hg}=1.36 \pm 0.06 ; \mathrm{n}=3\right)$ showed the highest methylation, whereas isotope

338 ratios in the samples from Sta. $\mathrm{B}\left(\mathrm{MM}^{199} \mathrm{Hg} / \mathrm{MM}^{200} \mathrm{Hg}=0.85 \pm 0.02 ; \mathrm{n}=3\right)$ were relatively

339 close to natural values $\left({ }^{199} \mathrm{Hg} /{ }^{200} \mathrm{Hg}=0.73\right)$. Stations $\mathrm{C}\left(\mathrm{MM}^{199} \mathrm{Hg} / \mathrm{MM}^{200} \mathrm{Hg}=1.05 \pm 0.11 ; \mathrm{n}\right.$

$340=3)$ and $\mathrm{D}\left(\mathrm{MM}^{199} \mathrm{Hg} / \mathrm{MM}^{200} \mathrm{Hg}=1.11 \pm 0.10 ; \mathrm{n}=3\right)$ showed intermediate and similar

$341 \mathrm{MM}^{199} \mathrm{Hg} / \mathrm{MM}^{200} \mathrm{Hg}$, yet clearly different from control samples (Fig. 6a). From these isotope

342 ratios, we estimated gross methylation rates between 0.009 and $0.083 \% \mathrm{~d}^{-1}$ with means of

$3430.010 \pm 0.001 \% \mathrm{~d}^{-1}$ (Sta. B), $0.020 \pm 0.005 \% \mathrm{~d}^{-1}$ (Sta. C), $0.029 \pm 0.010 \% \mathrm{~d}^{-1}$ (Sta. D), and

$3440.059 \pm 0.021 \% \mathrm{~d}^{-1}$ (Sta. A). Incubations of unfiltered bottom water showed changing

$345 \mathrm{MM}^{199} \mathrm{Hg} / \mathrm{MM}^{200} \mathrm{Hg}$ over time, reaching values of up to 8.7 after $192 \mathrm{~h}$ of incubation $(\mathrm{n}=2$,

346 data not shown). The estimated methylation potentials for unfiltered bottom water ranged

347 from $0.00019 \% \mathrm{~d}^{-1}$ (after 48 h) to $0.00043 \% \mathrm{~d}^{-1}$ (after 96 and 192 hours; Fig 6b). 


\section{$350 \quad$ 5.1. External sources of $\mathrm{MeHg}$}

\section{5.1.1. Advection from open sea}

352 In the North Gyre, the MeHgT UNF concentrations varied from values below DL to 0.48 pmol

$353 \mathrm{~L}^{-1}$ (Table 3), which is similar in magnitude to those reported in the last ten years for the open

354 Western Mediterranean waters (Cossa and Coquery, 2005; Kotnik et al., 2007; Cossa et al.,

3552009 and Heimbürger et al., 2010). The vertical MeHgT distribution patterns (Fig. 5) are

356 consistent with the now classical oceanic MeHg behavioral model characterized by (i) a

357 microbial net methylation within the oxycline, and (ii) a photodemethylation in surface

358 waters. Photochemical demethylation is well documented in experimental and natural

359 conditions (Suda et al., 1993; Black et al., 2012; Kim et al., 2016), whereas microbial

360 methylation is supported by the occurrence of a peak of MeHg in the ODZs (e.g., Mason and

361 Fitzgerald, 1990; Cossa et al., 2009; Sunderland et al., 2009). This model has recently been

362 supported by isotopic Hg compositions observed in the waters of the Pacific Ocean (Blum et

363 al., 2013). At stations L-10 and L-12, where water stratification was well established (Fig.

$364 \mathrm{~S} 3), \mathrm{O}_{2}$-deficient Leventine Intermediate Water and maximum $\mathrm{MeHgT}$ concentrations were

365 found between 200 and 400 m (Fig. 5a). For these two stations, and additionally Sta. M-10,

366 statistically significant $(p<0.01)$ relationships between $\mathrm{MeHgT}\left(\mathrm{pmol} \mathrm{L}^{-1}\right)$ and dissolved $\mathrm{O}_{2}$

367 ( $\mu \mathrm{mol} \mathrm{L} \mathrm{L}^{-1}$ ) exist (Fig. 7a), with similar regression coefficients, averaging $-0.0063 \pm 0.0001$.

368 For other stations, which comprise coastal sites (Stas. L-01, L-03 and M-12) and/or well

369 mixed water column (Sta. S2400), the correlations were weak or inexistent. The

370 corresponding average regression coefficient obtained for the relationships between $\mathrm{MeHgT}$

371 and apparent oxygen utilization (AOU) is $+0.0059 \pm 0.0007$, which is close to the value 
372 calculated for the whole Western Mediterranean $\left(+0.0039, \mathrm{R}^{2}=0.77, \mathrm{n}=40\right.$, according to

373 Cossa et al., 2009). In various parts of the World Ocean analogous distribution patterns have

374 been observed, showing undetectable methylated $\mathrm{Hg}$ concentrations in surface waters and

375 peaks deeper in the water column, where $\mathrm{O}_{2}$ reaches a minimum due to organic carbon

376 remineralization (e.g., Mason and Fitzgerald, 1990; Cossa et al., 2009; Sunderland et al.,

377 2009; Cossa et al., 2011). According to the model, settling particulate organic carbon is both a

378 source of $\mathrm{Hg}^{\mathrm{II}}{ }_{i}$ to microbiologically-active waters and a source of organic matter to sustain

379 bacterial activity. A specific gene cluster is linked to $\mathrm{Hg}$ methylation in a variety of

380 microorganisms, including sulfate and iron-reducing bacteria and others (Park et al., 2013;

381 Gilmour et al., 2013).

382 Furthermore, we observed here more significant regression coefficient with a steeper

383 slope for the inverse relationship between $\mathrm{DMHg}$ and dissolved $\mathrm{O}_{2}$ compared to that for

$384 \mathrm{MMHg}$ and dissolved $\mathrm{O}_{2}$ (Fig. 7b), suggesting that the organic matter regeneration is more

385 directly connected to DMHg formation than MMHg formation. This fact is consistent with the

386 hypothesis proposed by Fitzgerald and Mason (1996) that MMHg in marine waters is not

387 formed directly, but is a degradation product of DMHg. The probability of this pathway is

388 reinforced by the observation that the highest $\mathrm{MMHg} / \mathrm{DMHg}$ ratios occur during the

389 convection period (Fig. S3), when the $\mathrm{O}_{2}$ depletion is limited and consequently net $\mathrm{Hg}$

390 methylation is depressed (Fig. 5b). However, recent results (e.g., Jonsson et al., 2016;

391 Sorensen et al. 2016) leave the question of the $\mathrm{Hg}$ methylation pathway in the ocean open to

392 debate.

393 The Northern Current is the main source of waters for the Gulf of Lions. The horizontal

394 flux across the shelf-open sea boundary has been estimated to vary at different periods of the 
395 year between 0.07 and $0.35 \times 10^{6} \mathrm{~m}^{3} \mathrm{~s}^{-1}$ (Durrieu de Madron et al., 2003). The same authors

396 also estimate a shelf-slope exchange as $\sim 10 \%$ of the along-slope transport, namely $0.2 \times 10^{6}$

$397 \mathrm{~m}^{3} \mathrm{~s}^{-1}$. The chemical characteristics of waters entering the shelf are well represented by $0-100$

$398 \mathrm{~m}$ water layer found at Sta. Antarès. Using a MeHgTunF mean concentration of $0.11 \pm 0.02$

399 pmol L-1 $(n=3)$, the MeHgT entering the shelf waters from the open sea via the Northern

400 Current can be estimated as $680 \pm 120 \mathrm{~mol} \mathrm{a}^{-1}$, representing $12 \%$ of the $\mathrm{HgT}$ flux.

\section{$401 \quad$ 5.1.2. Atmospheric deposition}

402 The MeHgT contribution from the atmospheric bulk wet deposition on the Gulf of Lions, 403 based on results from section 4.1 and a surface area of the Gulf of $12 \times 10^{3} \mathrm{~km}^{2}$, can be 404 calculated as $2.5 \pm 1.4 \mathrm{~mol} \mathrm{a}^{-1}$. In the absence of quantifiable analytical determinations, we 405 assume a MeHgT dry deposition similar to the wet (as it is for the HgT in the Mediterranean 406 environment according to Cossa and Coquery, 2005). Thus, the total MeHgT deposition into 407 the waters of the Gulf of Lions can be estimated at $\sim 5 \mathrm{~mol} \mathrm{a}^{-1}$, which is $2 \%$ of the total $\mathrm{HgT}$ 408 deposition.

\section{$409 \quad$ 5.1.3. Riverine and groundwater inputs}

410 The amount of MeHgT transported annually by the Rhône River into the Gulf of Lions waters 411 is estimated to be $5 \mathrm{~mol} \mathrm{a}^{-1}$ for the dissolved phase and $51 \mathrm{~mol} \mathrm{a}^{-1}$ for the particulate phase

412 (see S1 2 for detailled calculation). Extrapolating these figures to transports from all the Gulf

413 of Lions rivers gives a continental surface runoff contribution of $5.8 \pm 2.0$ and $59.7 \pm 28.1$

$414 \mathrm{~mol} \mathrm{a}^{-1}$, for the dissolved and particulate MeHgT, respectively. The conservative mixing of

415 dissolved MeHg between fresh and marine waters (Fig. 2a) allows an estimation of the annual 416 net MeHgT efflux to the Gulf of Lions as equal to the gross efflux calculated above. Based on 417 previous results, and owing to the fact that the Rhône River provides $85 \%$ and $83 \%$ all 
418 riverine dissolved and solid discharges respectively (Gairoard et al., 2012), the total riverine

419 MeHg flux (dissolved + particulate) to the Gulf ranges within $53.3-77.7 \mathrm{~mol} \mathrm{a}^{-1}$, with a $99 \%$

420 probability. At the scale of the Gulf of Lions, this mean flux is equivalent to $\sim 10 \%$ of the

421 MeHgT flux from marine source. To this surface runoff, the potential contribution of

422 groundwater should be added (Black et al. 2009b; Ganguli et al., 2012). In the absence of

423 direct measurement, a hypothetical estimate can be performed. Assuming values of

424 groundwater discharges to the Gulf of Lions of 2-30\% of the riverine discharge (Ollivier et

425 al., 2008), and MeHgT concentrations in groundwater similar to the only figures available to

426 date - i.e., those measured along the Southern Californian coasts $\left(0.2-1.0 \mathrm{pmol} \mathrm{L}^{-1}\right.$, according

427 to Ganguli et al., 2012) -, we can approximate the MeHgT contribution of submarine

428 freshwater discharges to the Gulf of Lions waters to be in the range $0.2-17.4 \mathrm{~mol} \mathrm{a}^{-1}$. Given

429 the large uncertainties in this estimate, the MeHgT contribution from groundwater sources

430 remains to be assessed based on direct measurements. However, we can conclude that the

431 continental water contribution (gross efflux) is $<95 \mathrm{~mol} \mathrm{a}^{-1}$ and small compared to open sea

$432\left(680 \pm 120 \mathrm{~mol} \mathrm{a}^{-1}\right)$ as a source of MeHgT for the Gulf of Lions.

\section{5.13. Efflux from the shelf sediments}

434 The shelf sediments can be a source of MeHgT via the diffusion of soluble phase from

435 pore water across the sediment-water interface, via biopumping, and via the resuspension of

436 the surficial sediments during storm events. All these processes have not been determined,

437 however, in order to compare their magnitude with other MeHg sources, a "maximum

438 potential efflux" of MeHg from sediment has been estimated.

439 The pore-waters of the shelf surface sediments are MeHgT-enriched compared to the

440 overlying waters (Table 4). Using a simplified diffusion model (SI 3), we can calculate 
441 potential diffusion effluxes from sediments varying from 0.2 to $2.6 \mathrm{pmol} \mathrm{m}^{-2} \mathrm{~d}^{-1}$ depending on 442 the shelf stations and averaging $1.1 \pm 0.8 \mathrm{pmol} \mathrm{m}^{-2} \mathrm{~d}^{-1}(\mathrm{n}=6)$. For the surface area of the Gulf 443 of Lions shelf, which is $12 \times 10^{3} \mathrm{~km}^{2}$, we estimate an annual potential diffusive flux of

$444 \mathrm{MeHgT}$ from the sediment of $4.7 \pm 3.5 \mathrm{~mol}$, a figure similar to the dissolved riverine input $445\left(5.8 \pm 2.0 \mathrm{~mol} \mathrm{a}^{-1}\right)$. However, such a flux is not supported by MeHgT distribution in the water 446 column of the shelf (Stas. A-E), since no vertical trend evoking a gradient near the bottom has 447 been observed (Fig. 4a). In addition, a diffusive Hg flux out of the sediment may be

448 counteracted by the presence of the oxic layer near the sediment surface, where upward 449 diffusing Hg species may be trapped (Muresan et al. 2007). On the continental shelf of the 450 Gulf of Lions, oxygen penetration depth in the sediments increases with water depth and 451 distance from shore (Pruski et al, 2015). Oxidised conditions can be restricted from some 452 millimeters to some centimeters in the proximal Rhône (20-30 m), extended down to 2-5 cm 453 at $60 \mathrm{~m}$ depth (Table 4 ) and to $5-10 \mathrm{~cm}$ offshore at $100 \mathrm{~m}$ depth. In the sediment cores 454 collected on the Gulf of Lions shelf during the CASCADE cruise, an oxic layer was always 455 present at the benthic interface (Table 4). This layer should act as an efficient barrier for 456 upward diffusion of the pore water $\mathrm{MeHgT}_{\mathrm{F}}$, by adsorption onto oxyhydroxides $\left(\log K d_{\mathrm{MeHg}}\right.$ 457 equal to 6.4 and 7.7 for $\mathrm{FeO}_{\mathrm{x}}$ and $\mathrm{MnO}_{\mathrm{x}}$, respectively, according to Muresan et al., 2007) or 458 onto organic matter associated with oxides according to the model by Feyte et al. (2010).

459 If diffusion of MeHgT from sediments is unlikely, MeHg advection from sediment via 460 bioirrigation and biopumping is more probable. Assuming this advective flux to be 3 times the 461 diffusion flux, as calculated by Hammerschmidt and Fitzgerald (2008) for the Northeastern 462 Atlantic coastal sediments, the biomediated MeHg efflux from sediments would be $\sim 14.1 \mathrm{~mol}$ $463 \mathrm{a}^{-1}$. 
465 alternative methylated $\mathrm{Hg}$ source for shelf waters. Assuming a 2-cm thick layer (with a mean 466 porosity of 0.82 , according to Cathalot et al., 2010) of MeHgT-enriched pore water 467 resuspended $\left(0.3 \pm 0.2\right.$ pmol L $\mathrm{L}^{-1}$ according to Table 4$)$ and $12 \times 10^{3} \mathrm{~km}^{2}$ for the Gulf of Lions 468 shelf surface area, the quantity of MeHgT mobilized at each storm event would be $0.07 \pm 0.05$ 469 mol. According to Guizien (2009) the magnitude of the period with waves higher than $1.5 \mathrm{~m}$ 470 on the Gulf of Lions shelf is around $10 \%$ of the year. This means that a maximum of 37 days 471 of resuspension (i.e., fifteen 2.5 days-long storm events, Bourrin et al., 2012; Dumas et al., 472 2014) can be estimated leading to the annual injection of $2.7 \pm 1.9 \mathrm{~mol}$ of MeHgT in the water 473 column. Thus, the "maximum potential efflux" of MeHg from the shelf sediment of the Gulf 474 of Lions would be $\sim 16.8 \mathrm{~mol} \mathrm{a}^{-1}$. Of course, factors such as demethylation at the sediment475 water interface as well as $\mathrm{MeHg}$ readsorption on resuspended particles may reduce this figure.

476 It is noteworthy that this "maximum potential efflux" is equivalent to $2.5 \%$ of the methylated $477 \mathrm{Hg}$ entering the Gulf of Lions from the sea and $28 \%$ of the riverine particulate MeHgT flux, 478 from which it partialy derives.

\section{5.2. Internal MeHg production}

\subsubsection{Shelf and slope waters}

481 The average of $\mathrm{MeHgT}_{\mathrm{F}}$ concentrations in the Low Salinity Waters was low $\left(<0.05 \mathrm{pmol} \mathrm{L}^{-1}\right)$ 482 and not different from the rest of the Gulf of Lions shelf waters ( $t$-test, $p>0.01$, Tables 2 and 483 3). The average $\mathrm{MeHgT}_{\mathrm{F}} / \mathrm{HgT}_{\mathrm{F}}$ ratio was $1.5 \%$. These low levels are consistent with active 484 photodemethylation in the surface waters (e.g., Black et al., 2012). The highest $\mathrm{MeHgT}_{\mathrm{F}}$ 485 concentrations occurred where highest salinities were present at the bottom of the Low

486 Salinity Waters lenses (Fig. 2b, Fig. 3), suggesting two possible origins for methylated Hg: its 
487 advection from the external sources quantified above (Northern Current waters and shelf

488 sediment) and/or its production in the shelf water column. Methylated Hg production

489 associated with planktonic production/degradation in the mixed layer has been shown already

490 in the Mediterranean Sea (Monperrus et al., 2007; Heimbürger et al., 2010) and elsewhere

491 (e.g., Lehnherr et al., 2011).

In the surface waters of the Low Salinity Waters, significant relationships exist between

$493 \mathrm{MeHgTP}$ and particulate phosphorus $\left(\mathrm{MeHgT}_{\mathrm{Ppmol}}{ }^{-1}=0.0723 \mathrm{P}_{\mathrm{P} \mu m o l} \mathrm{~L}^{-1}-0.0048, \mathrm{R}^{2}=0.44\right.$,

$4940.01<p<0.05$, Fig. S4a), and between $\mathrm{MeHgT}_{\mathrm{P}}$ and total pigments $\left(\mathrm{MeHgT}_{\mathrm{Ppmol}}{ }^{-1}=\right.$

$4950.0044 \mathrm{Pig}_{\mu g} \mathrm{~L}^{-1}-0.0078, \mathrm{R}^{2}=0.43,0.01<p<0.05$, Fig. S4b). This relationship suggests

496 methylated Hg accumulation in the phytoplankton of the Low Salinity Waters; however, its

497 origin is unidentified. Interestingly, $\mathrm{MeHgT}_{\mathrm{P}}$ is significantly inversely correlated with the

$498 \mathrm{MeHgT}_{\mathrm{F}}$ in Low Salinity Water surface waters $\left(\mathrm{MeHgT}_{\mathrm{Fpmol}}{ }^{-1}=-0.600 \mathrm{MeHgT}_{\mathrm{Ppmol} \mathrm{L}}{ }^{-1}+\right.$

$4990.030, \mathrm{R}^{2}=0.46, p<0.05$, Fig. S5). With a regression coefficient not different from $1(-0.600$

$500 \pm 0.415 ; p=0.05$ ), this relationship suggests that the two phases were exchanging the MeHgT

501 standing stock present in the water.

502 Along the slope (Sta. S230), $\mathrm{MeHgT}_{\mathrm{UNF}}$ distribution is related to soluble reactive

503 phosphorus (SRP) with the following relationship: $\mathrm{MeHgT}_{\mathrm{UNFpmol}} \mathrm{L}^{-1}=0.92 \mathrm{SRP}_{\mu \mathrm{mol}} \mathrm{L}^{-1}+0.04$

$504\left(\mathrm{R}^{2}=0.95, p<0.01\right)$. The regression coefficient is in the range of values reported for open

505 Mediterranean waters, namely 0.89 to 1.24 (see Table 2 in Cossa et al., 2009). These values

506 calculated for unfiltered samples are more than 10 times higher than the regression coefficient

507 for the relationship between $\mathrm{MeHg}_{\mathrm{P}}$ and $\mathrm{P}_{\mathrm{P}}$ mentioned above (0.0723). If the mineralization of

508 settling particules were responsible for the $\mathrm{MeHg}_{\mathrm{F}}$ versus SRP relationship, similar regression

509 coefficients should be found for the particulate and the dissolved phases. On the other hand, 
510 the discrepancy in the regression coefficients between $\mathrm{MeHg}_{\mathrm{F}}$ vs SRP and $\mathrm{MeHg}_{\mathrm{P}}$ vs $\mathrm{P}_{\mathrm{P}}$

511 suggests that MeHg-enriched water is advected with Northern Current and/or that net $\mathrm{Hg}$

512 methylation occurs in the organic matter regeneration zone of the slope water column. The

513 significant increase in $\mathrm{MeHgT}$ concentrations in the slope waters when dissolved oxygen

514 decreases $\left(\mathrm{R}^{2}=0.90 ; \mathrm{n}=21, p<0.01\right)$ supports this latter interpretation (Fig. S6).

515 In summary, net $\mathrm{Hg}$ methylation seems to occur along the slope water column, whereas

516 we find little evidence for it to occur in the Low Salinity Water lenses drifting on the Gulf of

517 Lions shelf. This observation probably indicates that particulate organic matter degradation,

518 which governs the $\mathrm{Hg}^{\mathrm{II}}{ }_{\mathrm{i}}$ methylation, is favored when the water column is deep enough to

519 sustain a sufficiently long residence time of settling particles. In contrast, on the shelf, where

520 the water column depth is limited, organic matter degradation mostly occurs in the surface

521 sediments. Incubation experiments allowed estimating the $\mathrm{Hg}$ methylation potentials within

522 the Gulf of Lions water and sediment.

\section{5.2.2. In situ Hg methylation potential}

524 Week-long (192 h) incubation experiments suggest gross $\mathrm{Hg}$ methylation $\mathrm{t}$ rates of 0.009 to

$525 \quad 0.083 \% \mathrm{~d}^{-1}$ during sediment resuspension. In addition, incubations of bottom seawater

526 sampled on the shelf during winter downwelling gave $\mathrm{Hg}$ methylation potentials (over $192 \mathrm{~h}$ )

527 ranging from 0.0002 to $0.0004 \% \mathrm{~d}^{-1}$. Interestingly, the methylation rates increased during the

528 first $96 \mathrm{~h}$ of incubation then remained constant at the maximum level after 96 to $192 \mathrm{~h}$ (Fig.

529 6b). Applying the above methylation potentials to the flux of inorganic particulate $\mathrm{Hg}$

530 calculated from the mean concentration of inorganic particulate Hg measured in March 2011

531 in the Gulf of Lions $\left(0.519 \mathrm{nmol} \mathrm{g}^{-1}\right)$ and the downwelling mass flux of $0.4 \times 10^{12} \mathrm{~g}$ per storm

532 event (2-3 days-long; Bourrin et al., 2012; Dumas et al., 2014), the gross methylation 
533 observed in sediment slurries may account at best for 0.02 to $0.17 \mathrm{~mol}^{-\mathrm{d}^{-1}} \mathrm{MeHgT}$ (i.e. 0.05 -

$5340.42 \mathrm{~mol} \mathrm{MeHgT} \mathrm{per} \mathrm{storm} \mathrm{event),} \mathrm{that} \mathrm{is} 0.7$ to $6.3 \mathrm{~mol}$ per year for 15 storms a year. These

535 considerations suggest that the contribution of MeHgT produced in sediment slurries resulting

536 from sediment resuspension in bottom water and short-term settling/resuspension cycles may

537 be similar in magnitude to $\mathrm{MeHgT}$ release from porewater $\left(2.7 \mathrm{~mol} \mathrm{a}^{-1}\right)$. If we apply the gross

538 methylation rates obtained in bottom water (up to $0.0004 \% \mathrm{~d}^{-1}$ ) to the whole water column

539 (with a $\mathrm{Hg}^{\mathrm{II}}{ }_{\mathrm{i}}$ of $0.85 \mathrm{pmol} \mathrm{L}^{-1}$ ), the maximum methylation rate in the entire Gulf of Lions

540 waters $\left(\sim 1.8 \times 10^{3} \mathrm{~km}^{3}\right)$ should not exceed $2.2 \mathrm{~mol} \mathrm{a}^{-1}$.

\section{SUMMARY AND CONCLUSIONS}

543 Reviewing the oceanic Hg biogeochemical cycle, Mason et al. (2012) sum up that, while

544 atmospheric deposition is the main source of inorganic divalent $\mathrm{Hg}$ in open ocean systems,

545 most of the MMHg accumulating in ocean fish should derive from in situ production in the

546 upper water column. Is this model proposed for the open seas also valid for the coastal

547 environment? Here, we have addressed the questions of the distribution and sources of

548 methylated Hg in the waters of the Northwestern Mediterranean margin including the

549 continental shelf (Gulf of Lions) and the adjacent open sea (North Gyre). In summary, it

550 appears that the proportion of methylated $\mathrm{Hg}$ to $\mathrm{HgT}$ increased seaward, from the freshwaters

551 (Rhône River waters) to the shelf waters (Gulf of Lions waters) and the open ocean (North

552 Gyre waters). Highest MeHgT concentrations are associated with the ODZs of the North

553 Gyre. Despite the observed in situ methylation of inorganic $\mathrm{Hg}$ in sediment and waters within

554 the system ( $<6.3$ and $\sim 2.2 \mathrm{~mol} \mathrm{a}^{-1}$, respectively), external methylated $\mathrm{Hg}$ sources are the

555 largest for the Gulf of Lions. The adjacent open ocean is the dominant source, with $680 \pm 120$ 
$556 \mathrm{~mol}$ of MeHg per year. Continental sources (river and groundwater) account for $<95 \mathrm{~mol} \mathrm{a}^{-1}$,

557 with MeHg being mainly associated with continental particulate matter, a phase which is not

558 directly available for pelagic biota. Contributions from atmospheric deposition and sediment

559 resuspension are estimated to be $\sim 5$ and $<16.8 \mathrm{~mol} \mathrm{a}^{-1}$, respectively. We conclude that (i) the

560 methylation of inorganic $\mathrm{Hg}$ in the ODZs of the open sea is the main source of methylated $\mathrm{Hg}$

561 in the Northwestern Mediterranean margin waters, and that (ii) sedimentary sources have a

562 lower influence on the distribution of $\mathrm{MeHgT}$ in the water column, even though high

563 methylated $\mathrm{Hg}$ concentrations in the sediments may cause the exposure of organisms feeding

564 on food webs linked to the benthic environment. Our findings underline the ecological

565 importance of the idea that, even in coastal contaminated environments, methylated $\mathrm{Hg}$

566 transfer into food webs is driven by the efficiency of processes that determine MeHgT inputs

567 to the water column (Sunderland et al., 2010; Chen et al., 2014). We are in favor of an

568 approach where, in coastal ecosystems, the origin of $\mathrm{MeHg}$ accumulated through pelagic and

569 benthic food webs are differentiated using stable $\mathrm{Hg}$ isotopes (Mason et al., 2012).

571 Acknowledgments: Thanks are due to Bernard Averty, Jean-François Chiffoleau, Nicole

572 Garcia, Christine Sotin and Roger Kerouel who participated to sampling or analytical works

573 and to captains and crews of R/V SUROIT (BIOPRHOFI cruise) and R/V ATALANTE (CASCADE

574 cruise). Special thank to François Dufois for his helpful comments and to Mac Vautour for

575 editing the English. The manuscript was greatly improved by numerous comments of one

576 refeer and the associated editor. This research received funding from the French National

577 Research Agency (EXTREMA project, N ${ }^{\circ}$ ANR-06-VULN-005), and the European

578 Commission's Seventh Program (HERMIONE project, N 226354), the Région Aquitaine 
579 (FEDER Aquitaine-1999-Z0061) and the MERMEX / MISTRALS project. It is a contribution 580 to the international LOICZ program.

581 


\section{References}

Aminot A. and Kérouel K. (2007) Dosage automatique des nutriments dans les eaux marines: méthodes en flux continu. Méthodes d'analyse en milieu marin. Editions Quae. 187 pages. ISBN 978-2-7592-0023-8.

Balcom P. H., Hammerschmid C. R., Fitzgerald W. F., Lamborg C. H. and O'Connor J. S. (2008) Seasonal distributions and cycling of mercury and methylmercury in the waters of New York/New Jersey Harbor Estuary. Mar. Chem., 109, 1-17.

Balcom P. H., Schartup A. T., Mason R. P. and Chen C. Y. (2015) Sources of water column methylmercury acrossmultiple estuaries in the Northeast U.S. Mar. Chem., 177, 721-730.

Barnett P.R.O., Watson J. and Connelly D. (1984) A multiple corer for taking virtually undisturbed samples from shelf, bathyal and abyssal sediments. Oceanol. Acta, 7, 399-408.

Black F. J., Conaway C. H. and Flegal A. R. (2009a) Stability of Dimethyl Mercury in Seawater and Its Conversion to Monomethyl Mercury. Environ. Sci. Technol., 43, 40564062.

Black F. J., Paytan A., Knee K. L., de Sieyes N. R., Ganguli P. M., Gray E. and Flegal A. R. (2009b) Submarine Groundwater Discharge of Total Mercury and Monomethylmercury to Central California Coastal Waters. Environ. Sci. Technol., 43, 5652-5659.

Black F. J., Poulain B. A. and Flegal A. R. (2012) Factors controlling the abiotic photodegradation of monomethylmercury in surface waters. Geochim. Cosmochim. Acta, $\mathbf{8 4}$, 492-507.

Blum J. D., Popp B. N., Drazen J., Choy C. A. and Johnson M. W. (2013) Methylmercury production below the mixed layer in the North Pacific Ocean. Nature Geosci., 6, 879-884.

Bourrin F., Durrieu de Madron X., Mahiouz K., Guery L. B. and Houpert L. (2012) Sediment resuspension observed by an optical slocum glider during a typical Mediterranean winter storm. Ocean Science Meeting 2012, Salt Lake City, USA.

Bourrin F., Many G., Durrieu de Madron X., Martín J., Puig P., Houpert L., Testor P., Kunesch S., Mahiouz K. and Béguery L. (2015) Glider monitoring of shelf suspended 
particle dynamics and transport during storm and flooding conditions. Cont. Shelf Res., 109, $135-49$.

612 Bowman K. L., Hammerschmidt C. R., Lamborg C. H. and Swarr G. (2015) Mercury in the 613 North Atlantic Ocean: The U.S. GEOTRACES zonal and meridional sections. Deep Sea $614 \quad$ Res. II, 116, 251-261.

615 Bradley P. M., Burns D. A., Riva-Murray K., Brigham M. E., Button D. T., Chasar L. C., 616 Marvin-DiPasquale M., Lowery M. A. and Journey C. A. (2011) Spatial and Seasonal 617 Variability of Dissolved Methylmercury in Two Stream Basins in the Eastern United 618 States. Environ Sci. Technol., 45, 2048-2055.

619 Buck C. S., Hammerschmidt C. R., Bowman K. L., Gill G. A. and Landing W. M. (2015) 620 Flux of Total Mercury and Methylmercury to the Northern Gulf of Mexico from U.S. 621 Estuaries. Environ. Sci. Technol., 49, 13992-13999.

622 Castelle S. (2010) Suivi des apports en mercure au Golfe du Lion par voies atmosphérique et 623 fluvial. Rapport Ifremer $N^{\circ}$ RST.DOP/BE /LBCM/025.

624 Cathalot C., Rabouille, Pastor L., Deflandre B., Viollier E., Buscail R., Grémare A., Treignier 625 C. and Pruski A. (2010) Temporal variability of carbon recycling in coastal sediments 626 influenced by rivers: assessing the impact of flood inputs in the Rhône River prodelta. 627 Biogeosciences, 7, 1187-1205.

628 Charmasson S., Radakovitch O., Arnaud M., Bouisset P. and Pruchon A. S. (1998) Long-core 629 profiles of ${ }^{137} \mathrm{Cs},{ }^{134} \mathrm{Cs},{ }^{60} \mathrm{Co}$ and ${ }^{210} \mathrm{~Pb}$ in sediment near the Rhône river (Northwestern 630 Mediterranean Sea). Estuaries, 21, 367-378.

631 Chen C. Y., Borsuk M. E., Bugge D. M., T. Hollweg D. M., Balcom P. H., Ward D. M., 632 Williams J. and Mason R. P. (2014) Benthic and Pelagic Pathways of Methylmercury 633 Bioaccumulation in Estuarine Food Webs of the Northeast United States. Plos One, 9 , 634 Issue 2, e89305, p.1-11.

635 Choe K.-Y. and Gill G. A. (2003) Distribution of particulate, colloidal, and dissolved mercury 636 in San Francisco Bay estuary. 2. Monomethyl mercury. Limnol. Oceanogr., 48, 1547-1556.

637 Clarkson T. W. and Magos L. (2006) The toxicology of mercury and Clarkson its chemical 638 compounds. Crit Rev Toxicol., 36, 609-662. 
639 Conaway C. H., Black F. J., Gault-Ringold M., Pennington J. T., Chavez F. P. and Flegal A. 640 R. (2009) Dimethylmercury in coastal upwelling waters, Monterey Bay, California.

641 Environ. Sci. Technol., 43,1305-1309.

642 Coquery M., Cossa D. and Sanjuan J. (1997) Speciation and Sorption of Mercury in Two 643 Macro-Tidal Estuaries. Mar. Chem., 58, 213-227.

644 Cossa D., Martin J.-M. and Sanjuan J. (1994) Dimethylmercury formation in the Alboran Sea. 645 Mar. Poll. Bull., 28, 381-384.

646 Cossa D., Coquery M., Gobeil C. and Martin J.-M. (1996) Mercury Fluxes at the Ocean 647 Margins. 229-247. In: Regional and Global Cycles of Mercury: Sources, Fluxes, and Mass 648 Balances. W. Baeyens, R. Ebinghaus and O. Vasiliev éditeurs. Kluwer Academic 649 Publishers, Dordrecht, The Netherlands.

650 Cossa D., Martin J.-M., Takayanagi K. and Sanjuan J. (1997) The Distribution and Cycling of 651 Mercury in the Western Mediterranean. Deep Sea Res. II, 44, 721-740.

652 Cossa D., Averty B., Breaudeau J. and Senard A.-S. (2003) Spéciation du mercure dissous 653 dans les eaux marines. Analytical methods for the marine environments. Ifremer and 654 French Ministry for Ecology and Sustainable Development publication MA0303.

655 Cossa D. and Coquery M. (2005) The Mediterranean mercury anomaly, a geochemical or a 656 biological issue. pp 177-208. In: The Mediterranean Sea. Handbook of Environmental 657 Chemistry, Vol 5. Saliot, A. editeur. Springer, 413 p. ISSN 1433-6863.

658 Cossa D., Averty B. and Pirrone N. (2009) The origin of methylmercury in open 659 Mediterranean waters. Limnol. Oceanogr., 54, 837-844.

660 Cossa D., Heimbürger L.-E., Lannuzel D., Rintoul S. R., Butler E. C. V., Bowie A. R., Averty 661 B., Watson R. J. and Remenyi T. (2011) Mercury in the Southern Ocean. Geochim. 662 Cosmochim. Acta, 75, 4037-4052.

663 Dumas C., Aubert D., Durrieu de Madron X., Ludwig W., Heussner S., Delsaut N., Menniti 664 C., Sotin C. and Buscail R. (2014) Storm-Induced transfer of particulate trace metals to the 665 deep-sea in the Gulf of Lion (NW Mediterranean Sea). Environ. Geochem. Health, 36, 666 995-1014. 
Durrieu de Madron X., Denis L., Diaz F., Garcia N., Guieu C., Grenz C., Loÿe-Pilot M.-D., Ludwig W., Moutin T., Raimbault P. and Ridame C. (2003) Nutrients and carbon budgets for the Gulf of Lion during the Moogli cruises. Oceanol. Acta, 26, 421-433.

Durrieu de Madron X., Wiberg P. L. and Puig P. (2008) Sediment dynamics in the Gulf of Lions: The impact of extreme events. Cont. Shelf Res., 28, 1867-1876.

Elbaz-Poulichet F., Garnier J.-M., Guan D. M., Martin J.-M. and Thomas A. J. (1996) The conservative behaviour of trace metals $(\mathrm{Cd}, \mathrm{Cu}, \mathrm{Ni}$ and $\mathrm{Pb})$ and as in the surface plume of stratified estuaries: Example of the Rhône river (France). Estuar. Coast. Shelf Sci., 42, 289310.

Feyte S., Tessier A., Gobeil C. and Cossa D. (2010) In situ adsorption of mercury, methylmercury and other elements by iron oxyhydroxides and organic matter in lake sediments. Appl. Geochem., 25, 984-995.

Fitzgerald W. F. and Mason R. P. (1996) The global mercury cycle: oceanic and anthropogenic aspects. 85- 108. In: Regional and Global Cycles of Mercury: Sources, Fluxes, and Mass Balances. W. Baeyens, R. Ebinghaus and O. Vasiliev éditeurs. Kluwer Academic Publishers, Dordrecht, The Netherlands.

Fitzgerald W. F., Lamborg C. H. and Hammerschmidt C. R. (2007) Marine biogeochemical cycling of mercury. Chem. Rev., 107, 641-662.

Gilmour C. C., Podar M., Bullock A. L., Graham A. M., Brown S. D., Somenahally A. C., Microorganisms from New Environments. Environ. Sci. Technol., 47, 11810-11820.

Gobeil C. and Cossa D. (1993) Mercury in the sediments and sediment pore waters in the

Guédron S., Huguet L., Vignati D. A. L., Liu B., Gimbert F., Ferrarin B. J. D., Zonta R.and Dominik J. (2012) Tidal cycling of mercury and methylmercury between sediments and water column in the Venice Lagoon (Italy). Mar. Chem., 130-131, 1-11. 
696 Guizien K. (2009) Spatial Variability of Wave Conditions in the Gulf of Lions (NW

697 Mediterranean Sea). Vie et Milieu-Life and Environment, 59, 261-270.

698 Hammerschmidt C. R., Fitzgerald W. F., Lamborg C. H., Balcom P. H. and Visscher P. T.

699 (2004) Biogeochemistry of methylmercury in sediments of Long Island Sound. Mar.

$700 \quad$ Chem., 90, 31-52.

701 Hammerschmidt C. R. and Fitzgerald W. F. (2006) Methylmercury cycling in sediments on

702 the continental shelf of southern New England. Geochim. Cosmochim. Acta, 70, 918-930.

703 Hammerschmidt C. R., Lamborg C. H. and Fitzgerald W. F. (2007) Aqueous phase

704 methylation as a potential source of methylmercury in wet deposition. Atmos. Environ., 41, $705 \quad 1663-1668$.

706 Hammerschmidt C. R. and Bowman K. L. (2012) Vertical methylmercury distribution in the 707 subtropical North Pacific Ocean. Mar. Chem., 132-133, 77-82.

708 Hedges J. I. and Stem J. H. (1984) Carbon and nitrogen determinations of carbonate709 containing solids. Limnol. Oceanogr., 29, 663-666.

710 Heimbürger L.-E., Cossa D., Marty J.-C., Migon C., Averty B., Dufour A. and Ras J. (2010) 711 Methyl mercury distributions in relation to the presence of nano and picophytoplankton in 712 an oceanic water column (Ligurian Sea, North-western Mediterranean). Geochim.

713 Cosmochim. Acta, 74, 5549-4459.

714 Hollweg T. A., Gilmour C. C. and Mason R. P. (2009) Methylmercury production in 715 sediments of Chesapeake Bay and the mid-Atlantic continental margin. Mar. Chem. 114, 716 86-101.

717 Hollweg T. A., Gilmour C. C. and Mason R. P. (2010) Mercury and methylmercury cycling in 718 sediments of the mid-Atlantic continental shelf and slope. Limnol. Oceanogr., 55, 27037192722.

720 Horvat M., Liang L., Azemard S., Mandić V., Villeneuve J.-P. and Coquery M. (1997)

721 Certification of total mercury and methylmercury concentrations in mussel homogenate 722 (Mytilus edulis) reference material, IAEA-142. Fresenius J. Anal. Chem., 358, 411-418. 
723 Horvat M., Kotnik J., Logar M., Fajon V., Zvonaric T. and Pirrone N. (2003) Speciation of 724 mercury in surface and deep-sea waters in the Mediterranean Sea. 2003. Atmos. Environ., 725 37, S93-S108.

726 Huguet L., Castelle S., Schäfer J., Blanc G., Reynouard C. and Jorand F. (2010) Mercury methylation rates of biofilm and plankton microorganisms from a hydroelectric reservoir in French Guiana. Sci. Total Environ., 408, 1338-1348.

Jensen S. and Jernelöv A. (1969) Biological methylation of mercury in aquatic organisms.

731 Jonsson S., Mazrui N. M. and Mason R. P. (2016) Dimethylmercury Formation Mediated by 732 Inorganic and Organic Reduced Sulfur Surfaces. Sci. Rep., 6, 27958; doi:

$733 \quad 10.1038 /$ srep27958.

734 Kim, M-K., Won, A-Y. and Zoh, K-D. (2016) The production of dissolved gaseous

735 mercury from methylmercury photodegradation at different salinity. Desal. Wat.

736 Treat., 57, 610-619.

737 Kotnik J., Horvat M., Tessier E., Ogrinc N., Monperrus M., Amouroux D., Fajon V., Gibičar 738 D., Žižek S., Sprovieri F. and Pirrone N. (2007) Mercury speciation in surface and deep 739 waters of the Mediterranean Sea. Mar. Chem., 107, 13- 30.

740 Lehnherr I., St. Louis V. L., Hintelmann H. and Kirk J. L. (2011) Methylation of inorganic 741 mercury in polar marine waters. Nature Geosci., 4, 298-302.

742 Lehnherr I. (2014) Methylmercury biogeochemistry: a review with special reference to Arctic 743 aquatic ecosystems. Environ. Rev. 22, 229on. dx.doi.org/10.1139/er-2013-0059.

744 Liang L., Horvat M. and Bloom N. S. (1994) An improved speciation method for mercury by $745 \mathrm{GC} / \mathrm{CVAFS}$ after aqueous phase ethylation and room temperature precollection. Talanta, $746 \quad 41,371-379$.

747 Luengen A. C. and Flegal A. R. (2009) Role of phytoplankton in mercury cycling in the San 748 Francisco Bay estuary. Limnol. Oceanogr., 54, 23-40.

749 Maillet G. M., Vella C., Berné S., Friend P. L., Amos C. L., Fleury T. J. and Normand A. 750 (2006) Morphological changes and sedimentary processes induced by the December 2003 
flood event at the present mouth of the Grand Rhône River (southern France). Mar. Geol., 234, 159-177.

753 Marion C., Dufois F., Arnaud M. and Vella C. (2010) In situ record of sedimentary processes

754 near the Rhône River mouth during winter events (Gulf of Lions, Mediterranean Sea).

$755 \quad$ Cont. Shelf Res., 30, 1095-1107.

756 Marusczak N., Larose C., Dommergue A., Yumvihoze E., Lean D., Nedjai R. and Ferrarri C.

757 (2011) Total mercury and methylmercury in high altitude surface snow from the French

$758 \quad$ Alps. Sci. Total Environ., 409, 3949-3954.

759 Marusczak N., Castelle S, de Vogüé B, Knoery J. and Cossa D. (2015) Seasonal Variations of

760 Total Gaseous Mercury at a French Coastal Mediterranean Site. Aerosol and Air Quality

$761 \quad$ Research, doi:10.4209/aaqr.2015.04.0219.

762 Mason R. P. (1991) The chemistry of mercury in the equatorial Pacific Ocean. PhD Thesis.

763 University of Connecticut, USA, 305 pp.

764 Mason R. P. and Fitzgerald W. F. (1990) Alkylmercury species in the equatorial Pacific.

$765 \quad$ Nature (Lond.), 347, 457-459.

766 Mason R. P., Fitzgerald W. F., Hurley J. P., Hanson A. K., Donaghay P. L. and Sieburth J. M.

767 (1993) Mercury biogeochemical cycling in a stratified estuary. Limnol. Oceanogr., 38,

$768 \quad 1227-1241$.

769 Mason R. P., Rolfhus K. R. and Fitzgerald W. F. (1998) Mercury in the North Atlantic Mar.

$770 \quad$ Chem., 61, 37-53.

771 Mason R. P. and Sullivan K. A. (1999) The distribution and speciation of mercury in the $772 \quad$ South and equatorial Atlantic. Deep-Sea Res. II, 46, 937-956.

773 Mason R. P., Choi A. L., Fitzgerald W. F., Hammerschmidt C. R., Lamborg C. H., Soerensen 774 A. L. and Sunderland E. M. (2012) Mercury biogeochemical cycling in the ocean and 775 policy implications. Environ. Res., 119, 101-117.

776 Millot C. and Taupier-Letage I. (2005) Circulation in the Mediterranean Sea, p. 29-66. In:

777 The Mediterranean Sea. Handbook of Environmental Chemistry, Vol 5. Saliot, A. editeur. 778 Springer, 413 p. ISSN 1433-6863. 
Monperrus M. (2004) Utilisation de traceurs isotopiques stables pour la spéciation du mercure et des butylétains : Application à l'étude de la biométhylation du mercure dans les environnements aquatiques. PhD Thesis. Université de Pau et Pays de l'Adour, France.

Monperrus M., Tessier E., Amouroux D., Leynaert A., Huonnic P. and Donard O. F. X. (2007) Mercury methylation, demethylation and reduction rates in coastal and marine surface waters of the Mediterranean Sea. Mar. Chem., 107, 49-63.

Morel A. and André J.-M. (1991) Pigment distribution and primary production in the western Mediterranean as derived and modeled from coastal zone color scanner observations. $J$. Geophys. Res. (Oceans), 96, 12685-12698.

Munson K. M., Lamborg C. H., Swarr G. J.and Saito M. A. (2015) Mercury Species concentrations and fluxes in the Central Tropical Pacific Ocean. Global Biogeochem. Cycle, doi:10.1002/2015GB005120. 1-21p.

Muresan B., Cossa, D. Jézéquel D., Prévot F. and Kerbellec S. (2007) The biogeochemistry of mercury at the sediment water interface in the Thau lagoon. 1. Partition and speciation. Estuar. Coast. Shelf Sci., 72, 472-484.

Muresan B., Cossa D., Coquery M. and Richard S. (2008) Mercury sources and transformations in a man-perturbed tidal estuary: The Sinnamary Estuary, French Guiana. Geochim. Cosmochim. Acta, 72, 5416-5430.

Murphy J. and Riley J. P. (1962) A modified single solution methode for the determination of phosphates in natural waters. Anal. Chem. Acta, 27, 31-36.

Naudin J.-J., Cauwet G., Chrétiennot-Dinet M.-J., Deniaux B., Devenon J.-L. and Pauc H. (1997) River discharges and wind influence upon particulate transfer at the land-ocean interaction: case study of the Rhône River plume. Estuar. Coast. Shelf Sci., 45, 303-316.

Noh S., Choi M., Kim E., Dan N. P., Thanh B. X., Van Ha N. T., Sthiannopkao S. and Han S. (2013) Influence of salinity intrusion on the speciation and partitioning of mercury in the Mekong River Delta. Geochim. Cosmochim. Acta, 106, 379-390.

Ollivier P., Claude C., Radakovitch O. and Hamelin B. (2008) TIMS measurements of ${ }^{226} \mathrm{Ra}$ and ${ }^{228} \mathrm{Ra}$ in the Gulf of Lion, an attempt to quantify submarine groundwater discharge. Mar. Chem., 109, 337-354. 
808 Ormaza-Gonzales F. I. and Statham P. J. (1996) A comparison of methods for the 809 determination of dissolved and particulate phosphorus in natural waters. Water Res., 30, $810 \quad 2739-2747$.

811 Ortiz V., Mason R. P.and Ward J. E. (2015) An examination of the factors influencing 812 mercury and methylmercury particulate distributions, methylation and demethylation rates 813 in laboratory-generated marine snow. Mar. Chem., 177, 753-762.

814 Parks J. M., Joh A., Podar M., Bridou R., Hurt R. A., Smith S. D., Tomanicek S. J., Qian Y., 815 Brown S. D., Brandt C. C., Palumbo A. V., Smith J. C., Wall J. D., Elias D. A. and Liang 816 L. (2013) The Genetic Basis for Bacterial Mercury methylation. Science, 339, 1332-1335.

817 Pruski A. M., Buscail R., Bourgeois S., Vétion G., Coston-Guarini J. and Rabouille C. (2015) 818 Biogeochemistry of fatty acids in a river-dominated Mediterranean ecosystem (Rhône 819 River prodelta, Gulf of Lions, France): Origins and diagenesis. Org. Geochem., 83-84, $820 \quad 227-240$.

821 Radakovitch O., Charmasson S., Arnaud M. and Bouisset P. (1999) Pb-210 and caesium 822 accumulation in the Rhône delta sediments. Estuar. Coast. Shelf Sci., 48, 77-92. 823 doi:10.1006/ecss.1998.0405.

824 Schartup A. T., Balcom P. H., Soerensen A. L., Gosnellc K. J., Calder R. S. D., Mason R. P. 825 and Sunderland E. M. (2015) Freshwater discharges drive high levels of methylmercury in 826 Arctic marine biota. PNAS, doi/10.1073/pnas.1505541112.

827 Sorensen A. L., Jacob D. J., Schartup A. T., Fisher J., Lehnherr I., St. Louis V., Heimbürger 828 L.-E., Sonke J. E., Krabbenhoft D. P. and Sunderland E.M. (2016) A mass budget for 829 mercury and methylmercury in the Arctic Ocean. Global Biogeochem. Cycles, 830 doi:10.1002/2015GB005280.

831 Stoichev T. R., Rodriguez Martin-Doimeadios C., Tessier E., Amouroux D. and Donard O. F. 832 X. (2004) Improvement of analytical performances for mercury speciation by on-line 833 derivatization, cryofocussing and atomic fluorescence spectrometry. Talanta, 62, 433-438.

834 Strickland J. D. H. and Parsons T. R. (1972) A Practical Handbook of Seawater Analysis. 835 Bull, Fish. Res. Board Can., 167, 311 pp. 
836 Suda I., Suda M., and Hirayama K. (1993) Degradation of methyl and ethyl mercury by 837 singlet oxygen generated from sea water exposed to sunlight or ultraviolet light. Arch. 838 Toxicol., 67, 365-368.

839 Sunderland E. M., Krabbenhoft D. P., Moreau J. W., Strode S. A. and Landing W. M. (2009) 840 Mercury sources, distribution, and bioavailability in the North Pacific Ocean: Insights from 841 data and models. Global Biogeochem. Cycles, 23, GB2010, doi:10.1029/2008GB003425.

842 Sunderland E. M., Dalziel J., Heyes A., Branfireun B. A., Krabbenhoft D. P. and Gobas F. A. 843 C. P. (2010) Response of a Macrotidal Estuary to Changes in Anthropogenic Mercury 844 Loading between 1850 and 2000. Environ. Sci. Technol., 44, 1698-1704.

845 Ulses C., Estournel C., Durrieu de Madron X. and Palanques A. (2008) Sediment transport in 846 the Gulf of Lion (NW Mediterranean): Impact of extreme storms and floods. Cont. Shelf 847 Res., 28, 2048-2070.

848 Wang F., Macdonald R. W., Armstrong D. A. and Stern G. A. (2012) Total and Methylated 849 Mercury in the Beaufort Sea: The Role of Local and Recent Organic Remineralization. $850 \quad$ Environ. Sci. Technol., 46, 11821-11828.

851 Weiss-Penzias P. S., Ortiz C. Jr., Acosta R. P., Heim W., Ryan J. P., Fernandez D., Collett J. 852 L. Jr. and Flegal A. R. (2012) Total and monomethyl mercury in fog water from the central 853 California coast. Geophys. Res. Lett., 39, L03804, doi:10.1029/2011GL050324, 2012

854 Weiss-Penzias P. S., Coale K., Heim W., Fernandez D., Oliphant A., Dodge C., Hoskins D., 855 Farlin J., Moranville R. and Olson A. (2016) Total- and monomethyl-mercury and major 856 ions in coastal California fog water: Results from two years of sampling on land and at sea. 857 Elementa: Science of the Anthropocene, 4: 000101, doi: 10.12952/journal.elementa.000101 
859 Figure 1. Study site in the Northwestern Mediterranean, with main circulation patterns.

860 Stations location during the CASCADE cruise (March 2011). Station coordinates are given in 861 Table S2.

862 Figure 2. Dissolved $\mathrm{MeHg}\left(\mathrm{MeHgT}_{\mathrm{F}}\right)$ versus salinity. (a) Estuarine mixing zone, (b) Low 863 Salinity Water lenses. The solid line represents the linear relationship between $\mathrm{MeHgT}_{\mathrm{F}}$ and 864 salinity $\left(\mathrm{MeHgT}_{\mathrm{F}}=-0.0025^{*} \mathrm{Sal}+0.1258, \mathrm{R}^{2}=0.76\right)$, which suggests conservative mixing.

865 Figure 3. Time series of dissolved methylmercury $\left(\mathrm{MeHgT}_{\mathrm{F}}\right)$ and salinity in the Low Salinity 866 Water lenses (LSWs) drifting on the Gulf of Lions' shelf and slope. Note that the LSW 867 lenses occur mainly in the top $0-20 \mathrm{~m}$ depth.

868 Figure 4. Methylmercury (MeHgT) vertical profiles in the water of the shelf (a) and the continental slope (b) of the Gulf of Lions. UNF subscribes refer to unfiltered samples. Error bars correspond to standard deviations of 2 to 4 samples collected during temporal

872 Figure 5. Vertical profiles of methylated mercury (MeHgT) in the North Gyre water column. (a) Unfiltered (MeHgT $\mathrm{UNF}$ ) water samples and (b) $\mathrm{MMHg} / \mathrm{DMHg}$ ratios.

874 Figure 6. (a) Isotopic composition of MeHgT after incubation (192 h) of slurries of surface 875 sediments in unfiltered bottom water and (b) gross methylation rates in incubations of 876 unfiltered seawater from the bottom of the shelf water column, showing increasing 877 methylation rates over time during the first $96 \mathrm{~h}$ of incubation followed by the highest and 878 constant methylation rates after 96h. Error bars represent standard deviation for multiple 879 analyses $(n=3)$ of the same sample. For the methylation rates, error bars estimated from 880 multiple injections of the same sample $(n=3)$ were smaller than symbol size.

881 Figure 7. Relationships between methylated mercury (MeHgT) and dissolved oxygen $\left(\right.$ Dissolved $\left.\mathrm{O}_{2}\right)$ 882 in unfiltered samples from the North Gyre stations. (a) Methylated mercury (MeHgT) and (b) 883 monomethylmercury (MMHg) and dimethylmercury (DMHg). The probability threshold $(p<0.01)$ is 884 reached for $\mathrm{R}^{2} \geq 0.55$. No dissolved $\mathrm{O}_{2}$ measurements were available for station “Antarès”. 
888 Table 1. Rhône River. A statistical summary of the concentrations in dissolved $\left(\mathrm{X}_{\mathrm{F}}<0.45 \mu \mathrm{m}\right)$ 889 and particulate $\left(\mathrm{X}_{\mathrm{P}}>0.45 \mu \mathrm{m}\right) \mathrm{HgT}$ and $\mathrm{MeHg}$, measured in the waters at Arles (Sta. SORA). HgT 890 values measured in 1994-1995 are from Cossa and Coquery (2005). SD: standard deviation; n: 891 number of samples.

\begin{tabular}{lcccc}
\hline & $\begin{array}{c}\mathrm{HgT}_{\mathrm{F}} \\
\left(\mathrm{pmol} \mathrm{L}^{-1}\right)\end{array}$ & $\begin{array}{c}\mathrm{HgT}_{\mathrm{P}} \\
\left(\mathrm{nmol} \mathrm{g}^{-1}\right)\end{array}$ & $\begin{array}{c}\mathrm{MeHg}_{\mathrm{F}} \\
\left(\mathrm{pmol} \mathrm{L}^{-1}\right)\end{array}$ & $\begin{array}{c}\mathrm{MeHg}_{\mathrm{P}} \\
\left(\mathrm{nmol} \mathrm{g}^{-1}\right)\end{array}$ \\
\hline Average $\pm \mathrm{SD}(\mathrm{n})$ & $2.45 \pm 2.05(24)$ & $0.85 \pm 0.45(27)$ & $0.100 \pm 0.035(23)$ & $0.017 \pm 0.008(26)$ \\
Min. - Max. & $0.40-9.25$ & $0.20-2.15$ & $0.035-0.185$ & $0.004-0.032$ \\
\hline
\end{tabular}

892

893

894

Table 2. Low Salinity Water lenses (LSW) and slope foot waters (SFW, Sta. S230). A statistical summary of $\mathrm{HgT}$ and $\mathrm{MeHgT}(\mathrm{MeHgT}=\mathrm{MMHg}+\mathrm{DMHg}$ ) measurements during the BIOPRHOFI cruise. Average \pm standard deviation (number of samples) and range (Min. - Max.). (*) mean and standard deviation were calculated with the 87 concentration values, which included 30 measurements lower than the detection limit, which have been put equal to the half of the

900 detection limit.

\begin{tabular}{lccc}
\hline & $\begin{array}{c}\mathrm{HgT} \\
\left.(\mathrm{pmol} \mathrm{L})^{-1}\right)\end{array}$ & $\begin{array}{c}\mathrm{MeHgT} \\
(\mathrm{pmol} \mathrm{L}-1)\end{array}$ & $\begin{array}{c}\mathrm{MeHgT} / \mathrm{HgT} \\
(\%)\end{array}$ \\
\hline $\begin{array}{l}\text { LSW }(1-50 \mathrm{~m} \text { layer; } \\
\text { bottom } \leq 120 \mathrm{~m}) \text { Filtered } \\
\text { samples }(<0.4 \mu \mathrm{m})\end{array}$ & $\begin{array}{c}1.57 \pm 0.74(84) \\
0.61-3.50\end{array}$ & $\begin{array}{c}0.021^{*} \pm 0.012 *(87) \\
<0.015-0.069\end{array}$ & $\begin{array}{c}1.5 \pm 1.0(84) \\
<0.3-5.5\end{array}$ \\
$\begin{array}{l}\text { SFW }(<100 \mathrm{~m} \text { layer; } \\
\text { bottom at 1386 m) }\end{array}$ & $1.22 \pm 0.13(3)$ & $0.13 \pm 0.10(7)$ & $10 \pm 7(3)$ \\
Unfiltered samples & $0.98-1.35$ & $0.026-0.241$ & $2-18$ \\
$\begin{array}{l}\text { SFW }(100-900 \mathrm{~m} \text { layer; } \\
\text { bottom at 1386 m) }\end{array}$ & $1.41 \pm 0.06(4)$ & $0.32 \pm 0.13(11)$ & $18 \pm 1(4)$ \\
Unfiltered samples & $1.33-1.48$ & $0.23-0.38$ & $16-20$ \\
\hline
\end{tabular}

901

902 
904 Table 3. Gulf of Lions shelf, slope and North Gyre waters (CASCADE cruise). Summary

905 statistics for $\mathrm{HgT}_{\mathrm{UNF}}$ and $\mathrm{MeHgT}_{\mathrm{UNF}}$ concentrations. Average \pm Standard deviation (number of

906 samples) and range (Min. - Max.). Station locations are indicated on figure 1 and coordinates

907 are given on table S2. (*) Values calculated with concentrations lower than the DL put equal to

908 the half of the DL.

\begin{tabular}{lccc}
\hline $\begin{array}{l}\text { Station } \\
\text { (water layer sampled) }\end{array}$ & $\begin{array}{c}\mathrm{HgT}_{\mathrm{UNF}} \\
\left(\mathrm{pmol} \mathrm{L}^{-1}\right)\end{array}$ & $\begin{array}{c}\mathrm{MeHgT}_{\mathrm{UNF}} \\
\left(\mathrm{pmol} \mathrm{L}^{-1}\right)\end{array}$ & $\begin{array}{c}\mathrm{MeHgT}_{\mathrm{UNF}} / \mathrm{HgT}_{\mathrm{UNF}} \\
(\%)\end{array}$ \\
\hline \multicolumn{4}{c}{ Inner shelf $($ bottom $<100 \mathrm{~m})$} \\
\hline $\mathrm{A}(1-90 \mathrm{~m})$ & $2.04 \pm 1.11(7)$ & $0.041 \pm 0.034(9)^{*}$ & $1.5 \pm 0.9(7)$ \\
$\mathrm{B}(1-90 \mathrm{~m})$ & $1.27-4.47$ & $<0.015-0.119$ & $0.6-3.4$ \\
$\mathrm{C}(1-90 \mathrm{~m})$ & $1.17 \pm 0.29(10)$ & $0.034 \pm 0.021(10)^{*}$ & $3.1 \pm 2.2(10)$ \\
& $0.78-1.61$ & $<0.015-0.066$ & $0.5-6.3$ \\
$\mathrm{D}(1-90 \mathrm{~m})$ & $1.40 \pm 1.08(10)$ & $0.007 \pm 0.009(11)^{*}$ & $0.9 \pm 1.8(10)$ \\
& $0.58-4.20$ & $<0.015-0.035$ & $0.1-6.0$ \\
$\mathrm{~A} / \mathrm{B} / \mathrm{C} / \mathrm{D}(1-90 \mathrm{~m})$ & $1.61 \pm 1.23(9)$ & $0.024 \pm 0.014(10)^{*}$ & $2.2 \pm 1.7(9)$ \\
& $0.92-3.80$ & $<0.015-0.048$ & $0.3-5.1$ \\
& $1.52 \pm 1.00(36)$ & $0.026 \pm 0.024(40)^{*}$ & $1.9 \pm 1.9(36)$ \\
\hline
\end{tabular}

Slope edge and head of the Cap de Creus canyon (bottom at 100-300 m)

\begin{tabular}{lccc}
\hline E $(2-290 \mathrm{~m})$ & $0.99 \pm 0.52(20)$ & $0.026 \pm 0.048(8)^{*}$ & $1.5 \pm 2.0(8)$ \\
$\mathrm{L}-01(5-250 \mathrm{~m})$ & $0.58-2.94$ & $<0.015-0.141$ & $0.3-4.7$ \\
& $1.07 \pm 0.10(6)$ & $0.033 \pm 0.023(6)$ & $3.0 \pm 1.8(6)$ \\
$\mathrm{M}-12(10-130 \mathrm{~m})$ & $1.00-1.26$ & $0.020-0.076$ & $1.8-6.1$ \\
& $1.02 \pm 0.12(4)$ & $0.049 \pm 0.006(4)$ & $4.8 \pm 0.8(4)$ \\
& $0.93-1.14$ & $0.042-0.056$ & $4.1-6.0$ \\
\hline
\end{tabular}

Slope foot (bottom at 900-1800 m)

\begin{tabular}{cccc}
\hline M-10 (10-1100 m) & $1.01 \pm 0.15(10)$ & $0.271 \pm 0.088(10)$ & $26.2 \pm 6.2(10)$ \\
& $0.66-1.13$ & $0.092-0.355$ & $13.9-33.4$ \\
$\mathrm{~L}-03(10-1860 \mathrm{~m})$ & $1.22 \pm 0.12(10)$ & $0.177 \pm 0.077(8)$ & $14.9 \pm 6.5(8)$ \\
& $1.13-1.53$ & $0.020-0.266$ & $1.3-22.0$ \\
\hline
\end{tabular}




\begin{tabular}{|c|c|c|c|}
\hline \multicolumn{4}{|c|}{ North Gyre (bottom at > $2000 \mathrm{~m}$ ) } \\
\hline \multirow[t]{2}{*}{ Antarès (10-2500m) } & $1.05 \pm 0.12(9)$ & $0.235 \pm 0.107(9)$ & $21.8 \pm 8.8(9)$ \\
\hline & $0.84-1.23$ & $0.090-0.375$ & $11.3-33.8$ \\
\hline \multirow[t]{2}{*}{ L-05 (10-2200 m) } & $1.04 \pm 0.04(10)$ & $0.252 \pm 0.040(9)$ & $24.3 \pm 3.9(9)$ \\
\hline & $0.98-1.11$ & $0.199-0.309$ & $18.8-30.1$ \\
\hline \multirow[t]{2}{*}{ L-08 (10-2150 m) } & $1.07 \pm 0.04(10)$ & $0.307 \pm 0.045(10)$ & $28.7 \pm 4.3(10)$ \\
\hline & $1.01-1.13$ & $0.263-0.394$ & $24.2-38.6$ \\
\hline \multirow[t]{2}{*}{ L-10 (10-2360 m) } & $1.02 \pm 0.12(10)$ & $0.314 \pm 0.113(10)$ & $30.2 \pm 8.4(10)$ \\
\hline & $0.82-1.11$ & $0.166-0.478$ & $20.3-43.2$ \\
\hline \multirow[t]{2}{*}{ L-12 (10-2500m) } & $1.13 \pm 0.18(10)$ & $0.237 \pm 0.079(10)$ & $21.3 \pm 5.1$ \\
\hline & $0.64-1.23$ & $0.136-0.398$ & $13.4-32.4$ \\
\hline \multirow[t]{2}{*}{$\mathrm{S} 2400(10-2400 \mathrm{~m})$} & $1.11 \pm 0.01(10)$ & $0.175 \pm 0.123(10)$ & $15.8 \pm 11.1(10)$ \\
\hline & $1.08-1.12$ & $0.020-0.326$ & $1.8-25.4$ \\
\hline \multirow[t]{2}{*}{ M-08 (10-2010m) } & $1.15 \pm 0.12(10)$ & $0.305 \pm 0.052(10)$ & $26.8 \pm 5.9(10)$ \\
\hline & $1.03-1.45$ & $0.245-0.367$ & $17.7-35.7$ \\
\hline \multirow[t]{2}{*}{ M-05 (10-2490 m) } & $1.14 \pm 0.04(10)$ & $0.216 \pm 0.062(10)$ & $18.8 \pm 5.5(10)$ \\
\hline & $1.05-1.19$ & $0.106-0.302$ & $10.0-26.9$ \\
\hline \multirow[t]{2}{*}{ M-03 (10-2580 m) } & $1.24 \pm 0.10(10)$ & $0.276 \pm 0.056(10)$ & $22.6 \pm 5.5(10)$ \\
\hline & $1.09-1.41$ & $0.137-0.320$ & $9.7-27.9$ \\
\hline \multirow[t]{2}{*}{ M-01 (10-2500 m) } & $1.06 \pm 0.24(10)$ & $0.278 \pm 0.132(10)$ & $24.7 \pm 8.7(10)$ \\
\hline & $0.53-1.24$ & $0.066-0.374$ & $8.9-34.6$ \\
\hline
\end{tabular}

909

910

911

912

913

914

915

916

917

918

919

920 
921 Table 4. Gulf of Lions shelf and North Gyre (CASCADE cruise). Summary statistics for MeHgTF

$922(<0.4 \mu \mathrm{m})$ in the first $2 \mathrm{~cm}$ of the sediment pore waters and bottom water $(10 \mathrm{~cm}$ above the water sediment

923 interface). The thickness of the oxidized layer $(\mathrm{cm})$ is based on the redox potential value. In italic and

924 brackets are the MeHgT concentrations ( $\mathrm{pmol} \mathrm{g}^{-1}$ ) in the solid phase.

925

\begin{tabular}{cccc}
\hline Station & $\begin{array}{c}\text { Oxidized layer thickness } \\
(\mathrm{cm})\end{array}$ & $\begin{array}{c}\text { MeHgT }\left(\mathrm{pmol} \mathrm{L}^{-1}\right) \\
\text { Pore water }\end{array}$ & $\begin{array}{c}\text { MeHgT }\left(\mathrm{pmol} \mathrm{L}^{-1}\right) \\
\text { Bottom water }\end{array}$ \\
\hline A-04 & 2 & Inner shelf $($ bottom $<100 \mathrm{~m})$ & 0.022 \\
B-05 & 3 & $0.071(4.0)$ & 0.008 \\
C-05 & 3 & $0.268(3.5)$ & 0.040 \\
D-06 & 4.5 & $0.684(3.0)$ & 0.040 \\
E-03 & - & $0.254(3.5)$ & 0.040 \\
E-08 & 4.5 & 0.259 & 0.040 \\
\hline
\end{tabular}

926

927 


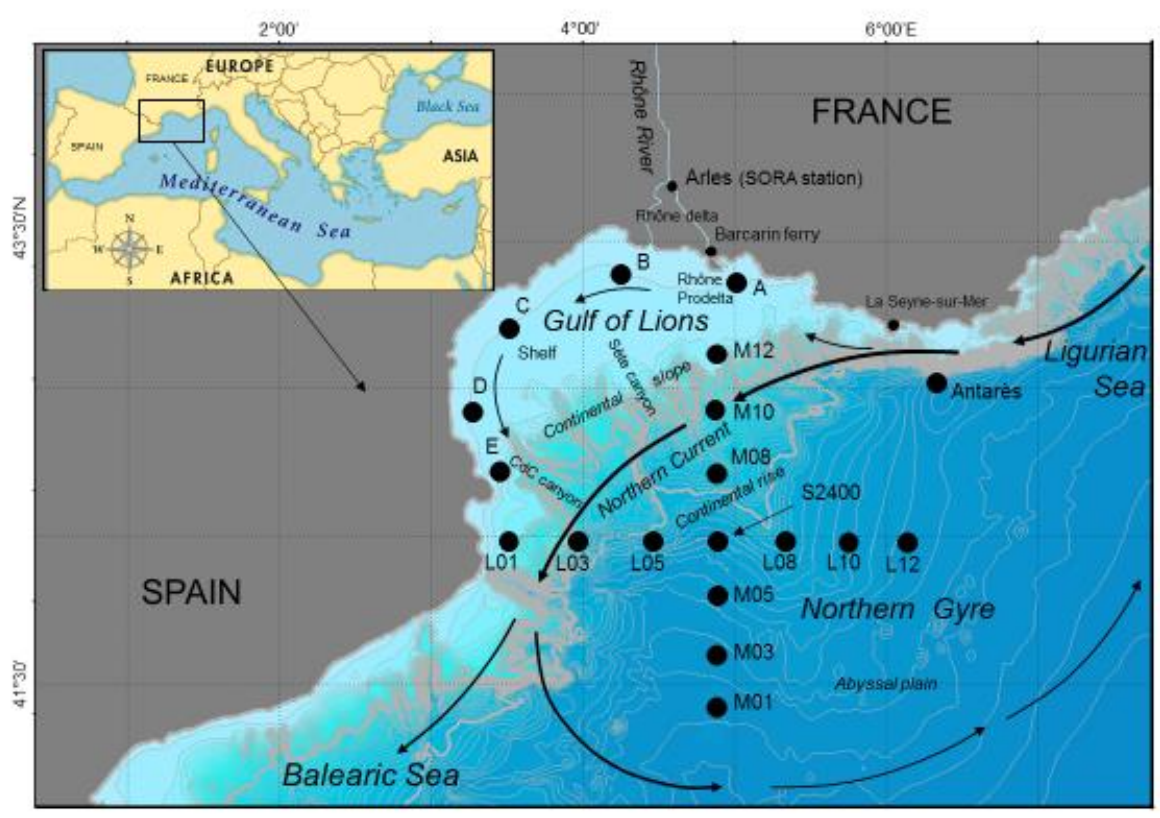

928

Fig. 1

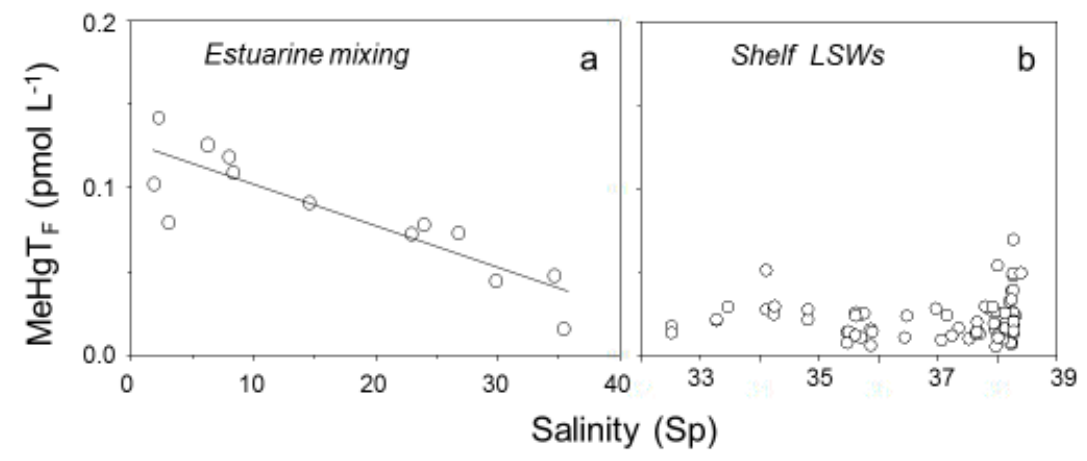

930

Fig. 2

931

932

933

934

935 


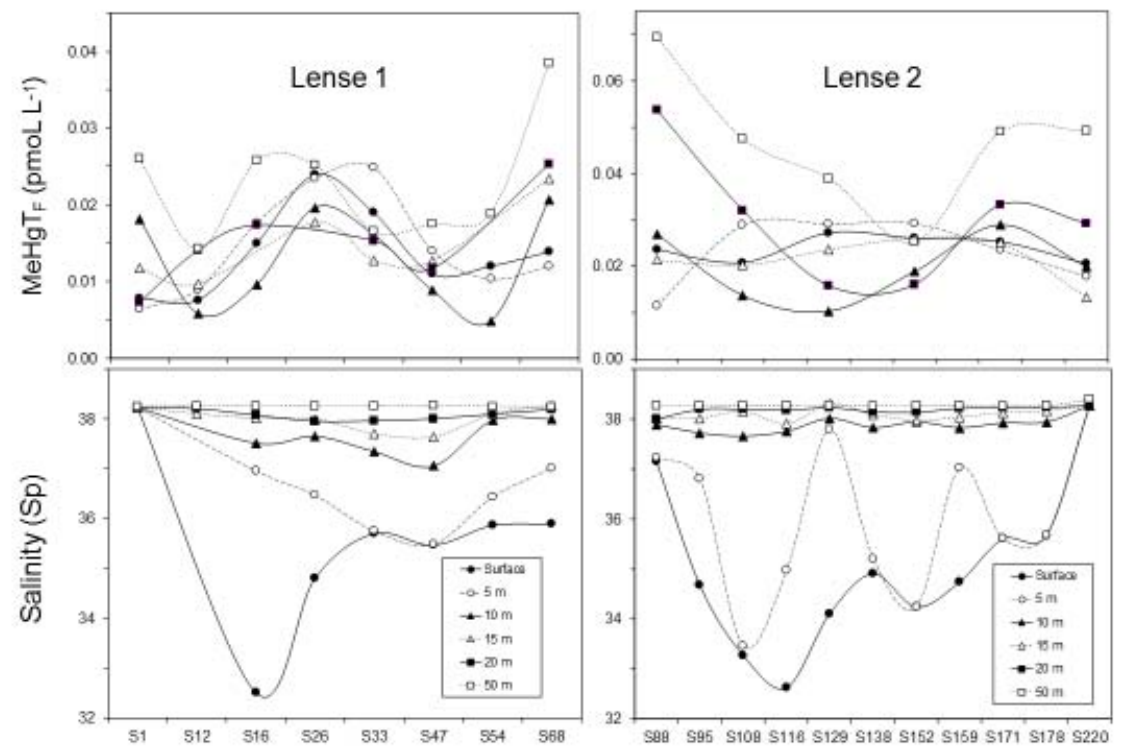

937

938

Fig. 3
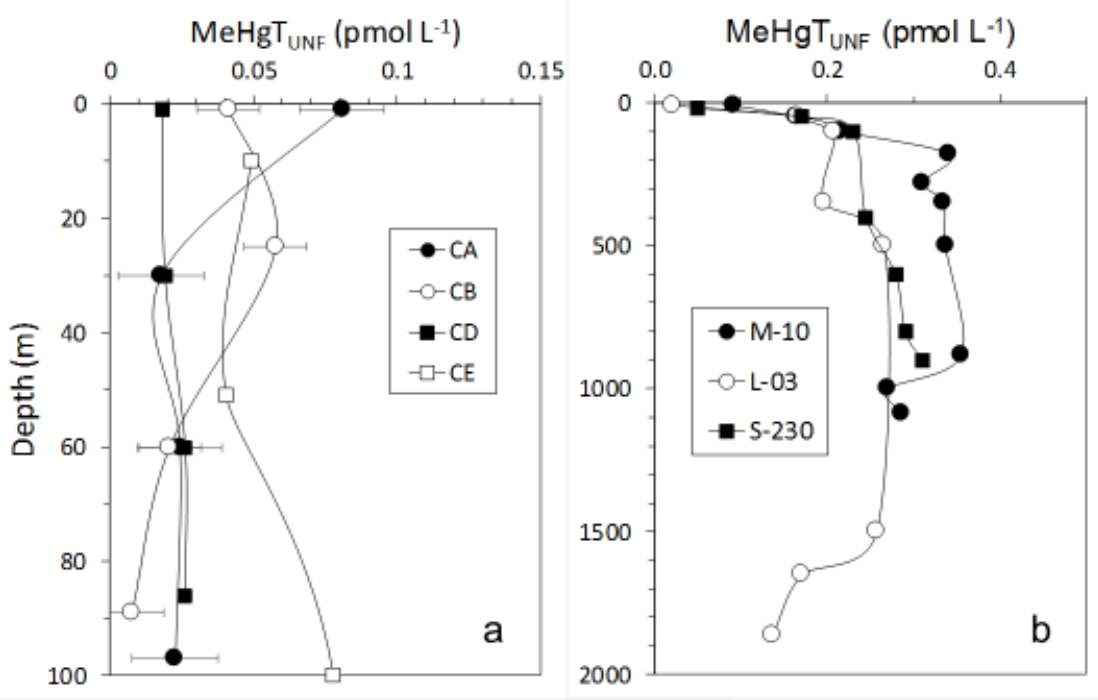

Fig. 4 


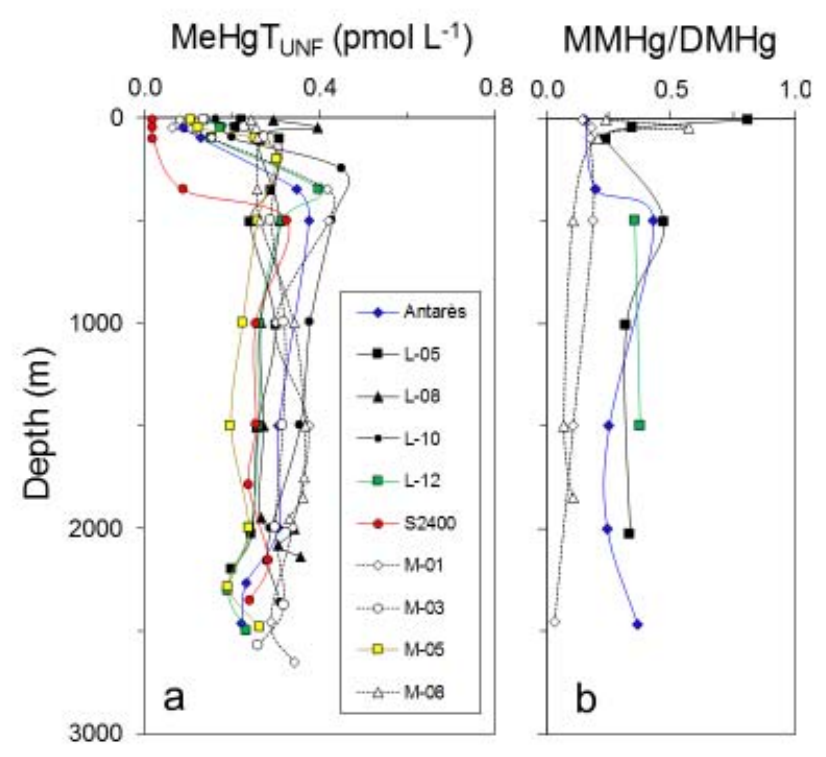

$946 \quad$ Fig. 5

947

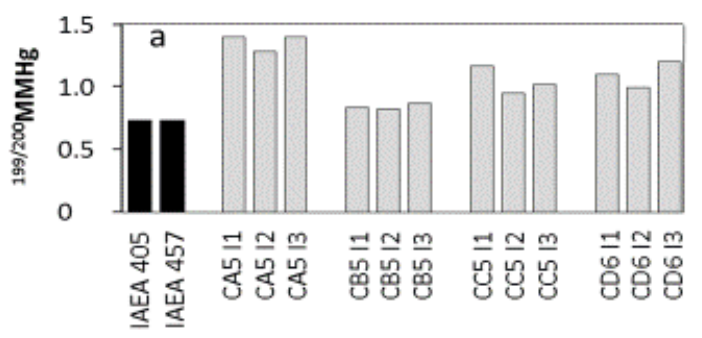

Fig. 6

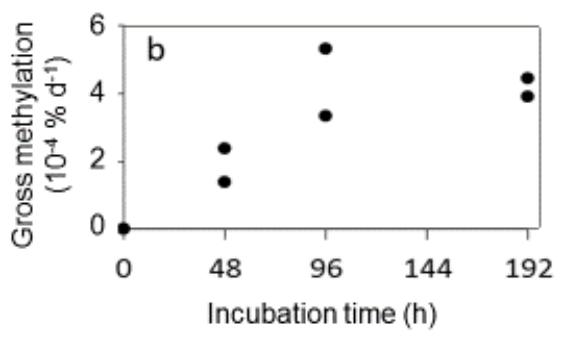



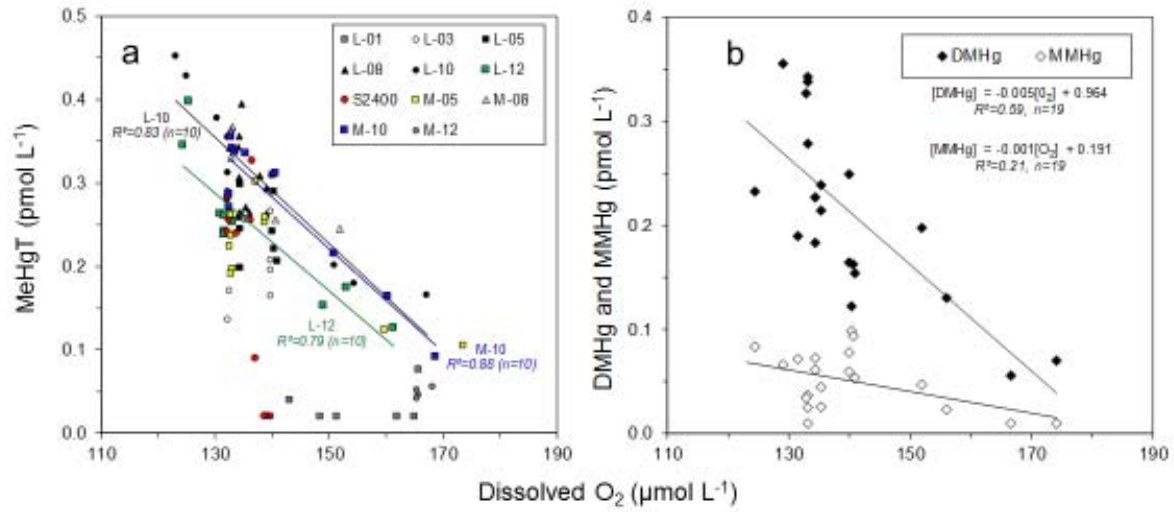

Fig. 7

955

956 

Suppl. Information (SI1, SI2 and SI3) and references

\section{Supplementary Figure Captions}

961 Figure S1. Schematic representation of the Gulf of Lions water circulation patterns.

962 Figure S2. Trajectories of the desalted water lenses (LSWs) drifting on the Gulf of Lions' shelf and 963 slope.

964 Figure S3. Potential temperature vertical profiles along the "L" transect (Fig. 1). Stratified stations are

965 characterized by high temperature gradients (red zones), whereas homogenized water column are 966 illustrated by a bleu monocolor.

967 Figure S4. Particulate methylmercury $\left(\mathrm{MeHg}_{\mathrm{P}}\right)$ versus (a) particulate phosphorus, and (b) pigments at 968 stations 221 and 230. See figure S2 for station locations.

969 Figure S5. Dissolved methylmercury versus particulate methylmercury in desalted water lenses (LSW) 970 drifting on the Gulf of Lions' shelf and slope. See figure S2 for station locations.

971 Figure S6. Dissolved methylmercury $\left(\mathrm{MeHg}_{\mathrm{F}}\right)$ versus dissolved oxygen within desalted water lenses 972 (LSW) drifting on the Gulf of Lions' shelf and slope. See figure S2 for station locations. 

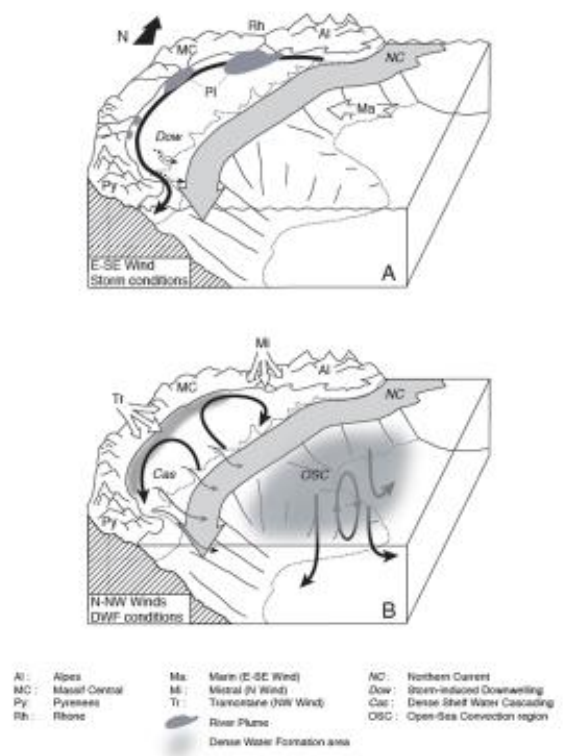

974

Fig. S1

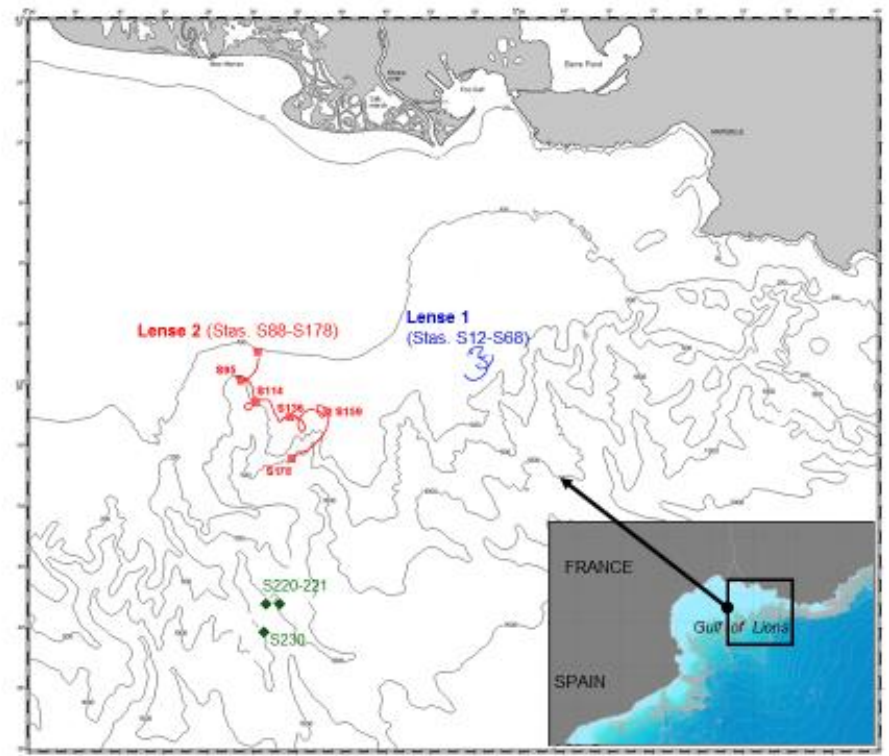

975

Fig. S2 


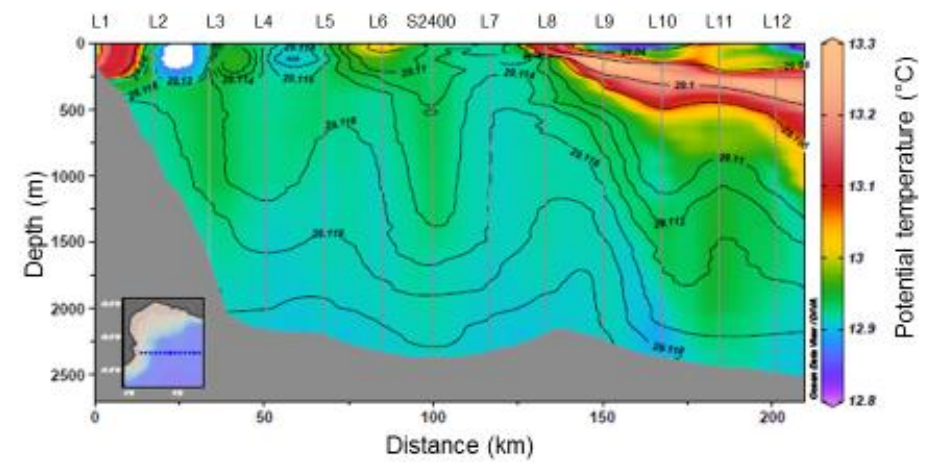

Fig. S3

976
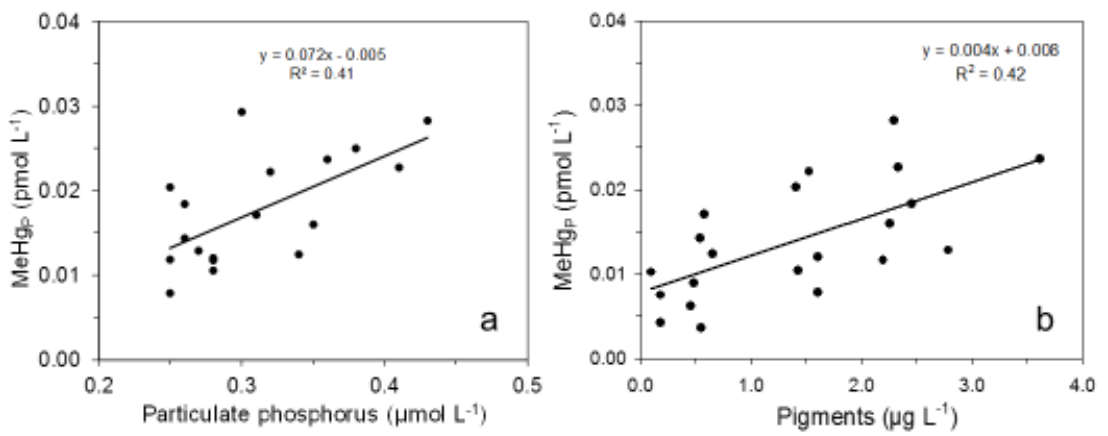

Fig. S4 


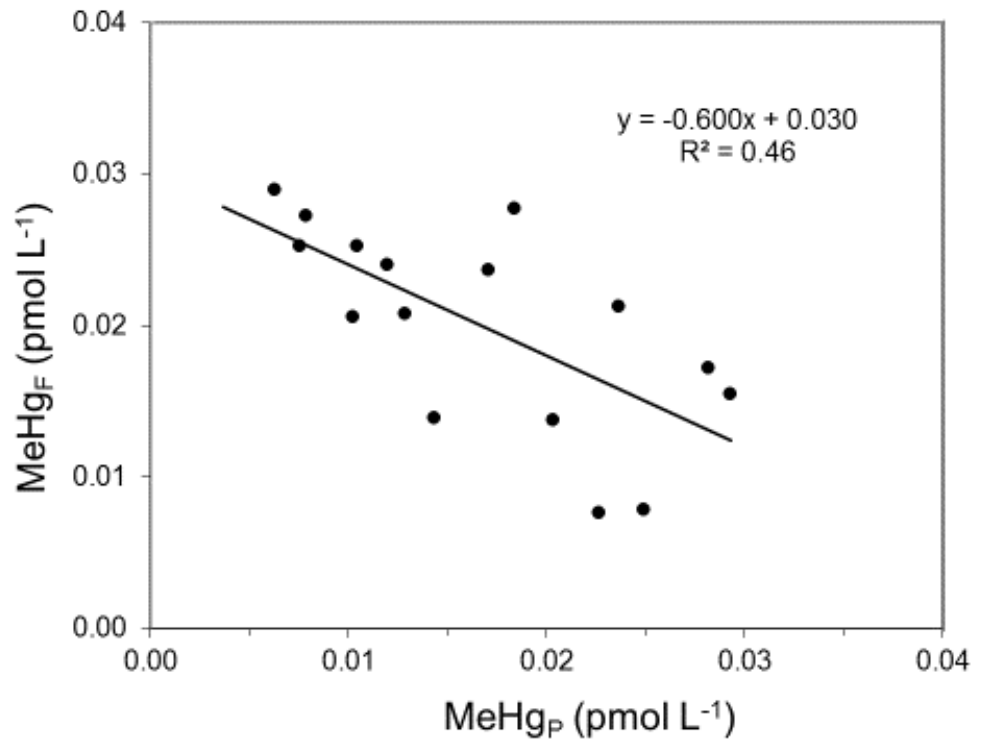

Fig. S5

978

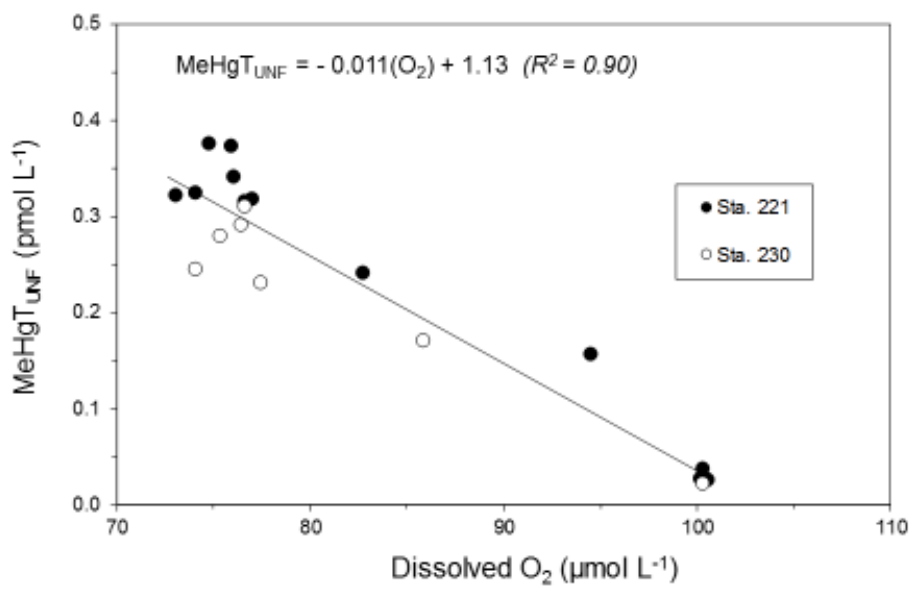

Fig. S6

979

980 
983 Table S1. Sampling cruises. (1) http://www.com.univ-mrs.fr/MOOSE/spip.php?article46; (2)

984 http://www.smtdr.fr/page5.html; (3) http://flotte.ifremer.fr/fleet/Presentation-of-the-fleet/Vessels/Deep-sea-

985 vessels/Le-Suroit/Virtual-tour-of-N-O-Le-Suroit; (4) http://flotte.ifremer.fr/fleet/Presentation-of-the-

986 fleet/Vessels/Deep-sea-vessels/L-Atalante. See also the map on figure 1.

987

\begin{tabular}{lllll}
\hline $\begin{array}{l}\text { Name of the } \\
\text { cruise }\end{array}$ & $\begin{array}{l}\text { Location of the } \\
\text { sampling }\end{array}$ & $\begin{array}{l}\text { Mode of } \\
\text { collection }\end{array}$ & Date & Type of samples collected \\
\hline $\begin{array}{l}\text { Rhône } \\
\text { monitoring } \\
\text { project }\end{array}$ & $\begin{array}{l}\text { Rhône River at } \\
\text { Arles }\end{array}$ & $\begin{array}{l}\text { SoRA } \\
\text { pumping } \\
\text { station }\end{array}$ & $\begin{array}{l}\text { April to June and } \\
\text { October to } \\
\text { November 2008 }\end{array}$ & Particles \\
\hline $\begin{array}{l}\text { Rhône delta } \\
\text { study }\end{array}$ & $\begin{array}{l}\text { Rhône fresh- } \\
\text { seawater mixing } 2009 \text { to June }\end{array}$ & $\begin{array}{l}\text { Barcarin } \\
\text { ferry }{ }^{2} \text { and } \\
\text { zone }\end{array}$ & October 2008 & $\begin{array}{l}\text { Filtered waters and } \\
\text { particles }\end{array}$ \\
\hline $\begin{array}{l}\text { BIOPRHOFI } \\
\text { cruise }\end{array}$ & Shelf and slope & $\begin{array}{l}\text { R/V Suroit } \\
\text { She }\end{array}$ & May 2006 & $\begin{array}{l}\text { Filtered waters and } \\
\text { particles }\end{array}$ \\
\hline $\begin{array}{l}\text { CASCADE } \\
\text { cruise }\end{array}$ & $\begin{array}{l}\text { Shelf, slope, } \\
\text { canyon and rise }\end{array}$ & $\begin{array}{l}\text { R/V } \\
\text { Atalante }\end{array}$ & March 2011 & $\begin{array}{l}\text { Filtered and unfiltered } \\
\text { waters. and particles }\end{array}$ \\
\hline $\begin{array}{l}\text { Atmospheric } \\
\text { monitoring }\end{array}$ & $\begin{array}{l}\text { Coastal site (La } \\
\text { Seyne-sur-Mer) }\end{array}$ & $\begin{array}{l}\text { Rain } \\
\text { collector }\end{array}$ & $\begin{array}{l}\text { Filtered and unfiltered } \\
\text { Jaters and sediment cores } \\
\text { (solid and pore waters) }\end{array}$ \\
\hline
\end{tabular}


Table S2a. Water sampling stations: Cruise, coordinates and bottom depth.

\begin{tabular}{|c|c|c|c|c|}
\hline Cruise & Station & Latitude $(\mathrm{N})$ & Longitude (E) & $\begin{array}{c}\text { Bottom } \\
\text { depth }(\mathrm{m})\end{array}$ \\
\hline Rhône River monitoring & SORA (Arles) & $43^{\circ} 40.722^{\prime}$ & $4^{\circ} .37 .278^{\prime}$ & 4 \\
\hline Rhône mixing zone & I-II & $43^{\circ} .15 .360^{\prime}$ & $4^{\circ} 26.460^{\prime}$ & 6 \\
\hline Rhône mixing zone & III-IV & $43^{\circ} 15.012^{\prime}$ & $4^{\circ} 26.892^{\prime}$ & 8 \\
\hline Rhône mixing zone & V-VII & $43^{\circ} 15.018^{\prime}$ & $4^{\circ} 26.862^{\prime}$ & 13 \\
\hline Rhône mixing zone & VIII-XIV & $43^{\circ} 13.758^{\prime}$ & $4^{\circ} 28.968^{\prime}$ & 10 \\
\hline BIOPRHOFI & $\mathrm{S} 12$ & $43^{\circ} 05.555^{\prime}$ & $4^{\circ} 47.848^{\prime}$ & 104 \\
\hline BIOPRHOFI & $\mathrm{S} 16 / 18$ & $43^{\circ} 02.395^{\prime}$ & $4^{\circ} 54.328^{\prime}$ & 123 \\
\hline BIOPRHOFI & S26 & $43^{\circ} 03.156^{\prime}$ & $4^{\circ} 55.379^{\prime}$ & 120 \\
\hline BIOPRHOFI & S33 & $43^{\circ} 02.857^{\prime}$ & $4^{\circ} 56.328^{\prime}$ & 123 \\
\hline BIOPRHOFI & $\mathrm{S} 47$ & $43^{\circ} 02.066^{\prime}$ & $4^{\circ} 57.294^{\prime}$ & 123 \\
\hline BIOPRHOFI & S54 & $43^{\circ} 02.008^{\prime}$ & $4^{\circ} 55.098^{\prime}$ & 123 \\
\hline BIOPRHOFI & S68 & $43^{\circ} 00.897^{\prime}$ & $4^{\circ} 54.132$ & 122 \\
\hline BIOPRHOFI & S88 & $43^{\circ} 03.014^{\prime}$ & $4^{\circ} 30.747^{\prime}$ & 103 \\
\hline BIOPRHOFI & S95 & $43^{\circ} 00.035^{\prime}$ & $4^{\circ} 28.624^{\prime}$ & 267 \\
\hline BIOPRHOFI & S108 & $42^{\circ} 58.267^{\prime}$ & $4^{\circ} 29.126^{\prime}$ & 358 \\
\hline BIOPRHOFI & S116 & $42^{\circ} 58.095^{\prime}$ & $4^{\circ} 31.054^{\prime}$ & 132 \\
\hline BIOPRHOFI & S129 & $42^{\circ} 56.984^{\prime}$ & $4^{\circ} 32.381^{\prime}$ & 131 \\
\hline BIOPRHOFI & S138 & $42^{\circ} 56.986^{\prime}$ & $4^{\circ} 34.895^{\prime}$ & 131 \\
\hline BIOPRHOFI & $\mathrm{S} 152$ & $42^{\circ} 57.621^{\prime}$ & $4^{\circ} 36.471^{\prime}$ & 127 \\
\hline BIOPRHOFI & S159 & $42^{\circ} 57.746^{\prime}$ & $4^{\circ} 38.387^{\prime}$ & 125 \\
\hline BIOPRHOFI & S171 & $42^{\circ} 55.144^{\prime}$ & $4^{\circ} 37.313^{\prime}$ & 269 \\
\hline BIOPRHOFI & $\mathrm{S} 178$ & $42^{\circ} 53.911^{\prime}$ & $4^{\circ} 34.218^{\prime}$ & 495 \\
\hline BIOPRHOFI & $\mathrm{S} 220$ & $42^{\circ} 42.374^{\prime}$ & $4^{\circ} 36.422^{\prime}$ & 971 \\
\hline BIOPRHOFI & S221 & $42^{\circ} 41.884$ & $4^{\circ} 32.451^{\prime}$ & 1122 \\
\hline BIOPRHOFI & $\mathrm{S} 230$ & $42^{\circ} 34.071^{\prime}$ & $4^{\circ} 27.957^{\prime}$ & 1386 \\
\hline CASCADE & Antarès & $42^{\circ} 48.150^{\prime}$ & $6^{\circ} 07.466^{\prime}$ & 2497 \\
\hline CASCADE & L01 & $42^{\circ} 01.950$ & $3^{\circ} 29.284^{\prime}$ & 239 \\
\hline CASCADE & L03 & $42^{\circ} 01.967$ & $3^{\circ} 53.250^{\prime}$ & 1887 \\
\hline CASCADE & L05 & $42^{\circ} 01.998^{\prime}$ & $4^{\circ} 17.400^{\prime}$ & 2199 \\
\hline CASCADE & L08 & $42^{\circ} 02.017^{\prime}$ & $5^{\circ} 06.067^{\prime}$ & 2166 \\
\hline
\end{tabular}




\begin{tabular}{|c|c|c|c|c|}
\hline CASCADE & L10 & $42^{\circ} 01.998^{\prime}$ & $5^{\circ} 30.150^{\prime}$ & 2398 \\
\hline CASCADE & $\mathrm{L} 12$ & $42^{\circ} 55.9845$ & $5^{\circ} 41.816^{\prime}$ & 2536 \\
\hline CASCADE & $\mathrm{S} 2400$ & $42^{\circ} 02.000^{\prime}$ & $4^{\circ} 41.533$ & 2391 \\
\hline CASCADE & M01 & $41^{\circ} 08.033^{\prime}$ & $4^{\circ} 41.750^{\prime}$ & 2691 \\
\hline CASCADE & M03 & $41^{\circ} 25.967^{\prime}$ & $4^{\circ} 41.783^{\prime}$ & 2614 \\
\hline CASCADE & M05 & $41^{\circ} 44.033^{\prime}$ & $4^{\circ} 41.466^{\prime}$ & 2522 \\
\hline CASCADE & M08 & $41^{\circ} 19.984^{\prime}$ & $4^{\circ} 41.816^{\prime}$ & 1979 \\
\hline CASCADE & M10 & $42^{\circ} 19.988^{\prime}$ & $4^{\circ} 41.850^{\prime}$ & 1096 \\
\hline CASCADE & M12 & $42^{\circ} 55.984^{\prime}$ & $4^{\circ} 41.816^{\prime}$ & 126 \\
\hline CASCADE & A-08 & $43^{\circ} 12.984^{\prime}$ & $04^{\circ} 50.371^{\prime}$ & 99 \\
\hline CASCADE & B-08 & $43^{\circ} 12.570^{\prime}$ & $04^{\circ} 07.670^{\prime}$ & 91 \\
\hline CASCADE & C-08 & $42^{\circ} 56.054^{\prime}$ & $03^{\circ} 29.580^{\prime}$ & 93 \\
\hline CASCADE & D-09 & $42^{\circ} 38.515^{\prime}$ & $03^{\circ} 18.408^{\prime}$ & 90 \\
\hline CASCADE & E-06 & $42^{\circ} 20.725^{\prime}$ & $03^{\circ} 21.414^{\prime}$ & 280 \\
\hline CASCADE & $\mathrm{X}-1$ to $\mathrm{X}-33$ & $42^{\circ} 20.867^{\prime}$ & $3^{\circ} 21.484^{\prime}$ & 290 \\
\hline & & & & \\
\hline Table S2b. & stations: Cruis & dinates and bo & depth. & \\
\hline Cruise & Station & Latitude $(\mathrm{N})$ & Longitude (E) & $\begin{array}{c}\text { Bottom } \\
\text { depth }(\mathrm{m})\end{array}$ \\
\hline CASCADE & A-04 & $43^{\circ} 18.092^{\prime}$ & $04^{\circ} 50.635^{\prime}$ & 57 \\
\hline CASCADE & B-05 & $43^{\circ} 20.375^{\prime}$ & $04^{\circ} 08.127^{\prime}$ & 64 \\
\hline CASCADE & C-05 & $43^{\circ} 03.382^{\prime}$ & $03^{\circ} 22.305^{\prime}$ & 60 \\
\hline CASCADE & D-06 & $42^{\circ} 40.594^{\prime}$ & $03^{\circ} 10.800^{\prime}$ & 61 \\
\hline CASCADE & E-03 & $42^{\circ} 19.951^{\prime}$ & $03^{\circ} 20.943^{\prime}$ & 120 \\
\hline CASCADE & E-08 & $42^{\circ} 21.106^{\prime}$ & $03^{\circ} 22.029^{\prime}$ & 442 \\
\hline CASCADE & S2400 & $42^{\circ} 01.985^{\prime}$ & $04^{\circ} 41.807^{\prime}$ & 2333 \\
\hline CASCADE & M01 & $41^{\circ} 08.005^{\prime}$ & $04^{\circ} 41.798^{\prime}$ & 2625 \\
\hline CASCADE & M08 & $42^{\circ} 19.989^{\prime}$ & $04^{\circ} 41.832^{\prime}$ & 1942 \\
\hline
\end{tabular}

1002

1003 


\section{SI1. Methods}

1006 Sample treatment

1007 Water and particles. The samples from the 0-50 m layer of the shelf waters during the BIOPRHOFI 1008 cruise were collected by pumping with an all-Teflon pneumatic pump (10-2PM, ASTI $\left.{ }^{\circledR}\right)$ and through

1009 polyethylene tubing, directly into a class 100 on-board container, with the consequence that the 1010 seawater was never in contact with the atmosphere of the ship. All the plastic wares were previously

1011 acid-cleaned according to ultraclean sample handling protocols (e.g., Cossa et al. 2003). Discrete water 1012 samples were collected in 2L Teflon (FEP) bottles inside the container, where filtrations were then 1013 performed on sub-samples using acid washed polycarbonate membranes $\left(0.45 \mu \mathrm{m}\right.$, Nuclepore $\left.{ }^{\circledR}\right)$.

1014 Filtrate $(250 \mathrm{~mL})$ was collected in Teflon (FEP) bottles and acidified with $\mathrm{HCl}(0.4 \%$, v/v, Suprapur,

$\left.1015 \operatorname{Merck}^{\circledR}\right)$ for subsequent analyses of "dissolved" fraction of total and methylmercury $\left(\mathrm{HgT}_{\mathrm{F}} \operatorname{and~} \mathrm{MeHgT}_{\mathrm{F}}\right)$.

1016 The collection of particles from the Low Salinity Waters, for subsequent $\mathrm{MMHg}_{\mathrm{P}}, \mathrm{CHNP}$ and pigments

1017 determinations, was performed using in-line filtration through glass fiber filters (GF/G, Whatman $\left.{ }^{\circledR}\right)$

1018 previously cleaned by heating at $450^{\circ} \mathrm{C}$ for $24 \mathrm{~h}$ and mounted in a Teflon (PTFE)/stainless steel filter

1019 holder $\left(\varnothing 142 \mathrm{~mm}\right.$, Schleicher \& Schuell $\left.{ }^{\circledR}\right)$ within the container. Up to 60 liters of water were filtered this

1020 way in order to collect enough material for the various particulate analyses. Samples for dissolved gaseous

$1021 \mathrm{Hg}(\mathrm{DGM})$ analyses were collected in a 1L Teflon bottle (FEP) according to the traditional method used

1022 for dissolved oxygen determination in order to avoid gas evasion during the collection. Deep-water

1023 samples $(>50 \mathrm{~m}$ ) were collected during the BIOPRHOFI and CASCADE cruises by rosette-mounted 5L

1024 bottles (1010X-Niskin, General Oceanics ${ }^{\circledR}$ ) equipped with a CTD probe. These samples were not

1025 filtered and analyzed only for $\mathrm{HgT}_{\mathrm{UNF}}$ and $\mathrm{MeHgT}_{\mathrm{UNF}}$. Dissolved gaseous $\mathrm{Hg}$ and $\mathrm{HgT}$ were

1026 determined on board, while MMHg and MeHgT analyses were performed in the laboratory within 2

1027 months after the cruise on the acidified samples stored in the dark at $+4^{\circ} \mathrm{C}$ in a double wrapping of

1028 polyethylene bags.

1029 Sediment cores: The cores were collected along the Gulf of Lions shelf, at the head of the Cap de

1030 Creus canyon and in the abyssal plain in the North Gyre area during the CASCADE cruise. A multicore

1031 sampler (Oktopus GmbH Multiple corer with 8 tubes of $100 \mathrm{~mm}$ diameter) allowing the sampling of

1032 the undisturbed benthic interface (Barnett et al., 1984) was used. The pore water was drained using

1033 Milli-Q (Millipore ${ }^{\circledR}$ ) water-rinsed microporous polymer tube samplers (Rhizon SMS, Rhizosphere

1034 Research Products ${ }^{\circledR}$ ) fixed on an acid washed all-polypropylene syringe (Guédron et al., 2012).

1035 Collected pore water (the two first $\mathrm{cm}$ below the water-sediment interface) was filtered through a 
1036 hydrophilic Teflon membrane $\left(0.45 \mu \mathrm{m}\right.$, Millex-LCR, Millipore $\left.{ }^{\circledR}\right)$, then acidified with high purity $\mathrm{HCl}$

$1037\left(0.4 \% \mathrm{v} / \mathrm{v}\right.$, Suprapur, Merck $\left.{ }^{\circledR}\right)$ and stored in the dark until MMHg analysis. According to Guédron et

1038 al. (2012), Rhizon samplers preferentially recover water from the sediment macropores, containing the

1039 readily exchangeable chemical species.

1040 Chemical analyses

1041 Total mercury. Total Hg in filtered and unfiltered samples were measured on board within a few 1042 minutes of sampling. In order to access all the mercury chemical species, present in the sample, the 1043 release of $\mathrm{Hg}$ from its ligands was achieved by a $\mathrm{BrCl}$ solution $(0.1 \mathrm{~mL}$ of a $0.2 \mathrm{M}$ solution is added to 1044 a $100 \mathrm{~mL}$ sample), and then the $\mathrm{Hg}^{\mathrm{II}}{ }_{\text {i }}$ was reduced to $\mathrm{Hg}^{0}$ with an acidic $\mathrm{SnCl}_{2}$ solution $(0.2 \mathrm{~mL}$ of a 1 $1045 \mathrm{M}$ solution is added to a $100 \mathrm{~mL}$ sample). This technique derives from the original Bloom and 1046 Crecelius (1983) method and has been described in detail by several authors (e.g., Gill and Fitzgerald, 1047 1988; Horvat et al., 1991; Mason and Fitzgerald, 1993) and is now known as the US-EPA standard 1048 method $\mathrm{N}^{\circ}$ 1631. The $\mathrm{Hg}^{0}$ vapor generated by the reduction is amalgamated on a gold (Au) trap then 1049 released by heating into an Atomic Fluorescence Spectrometer (2500, Tekran ${ }^{\circledR}$ ). For both 1050 measurements, the detection limit (DL) was $0.1 \mathrm{pmol} \mathrm{L}^{-1}$ and the reproducibility varied according to 1051 the concentration level between 5 and $15 \%$ (Cossa et al. 2003). The accuracy of HgT measurements 1052 was tested using the ORMS-3 certified reference material (CRM) from the National Research Council 1053 of Canada. Our measurements were always within the confidence limits given for the CRM (12.6 \pm 1.1 1054 pg mL ${ }^{-1} ;$ http://inms-ienm.nrc-cnrc.gc.ca/calserv/crm_files_f/ORMS-3_f.pdf).

1055 Methylated Hg species. Total methylated Hg and MMHg were measured on filtered and unfiltered 1056 samples, whereas DMHg was not measured, but calculated as the difference between $\mathrm{MeHgT}_{\mathrm{UNF}}$ and $1057 \mathrm{MMHg}_{\mathrm{UNF}}$. Total methylated $\mathrm{Hg}$ was determined on acidified samples, which means that both $\mathrm{MMHg}$ 1058 and DMHg were determined in the same time, since DMHg is converted into MMHg at low pH 1059 (Mason, 1991; Black et al., 2009a). Monomethyl Hg was determined with the same technique as 1060 MeHgT, but after bubbling $350 \mathrm{~mL}$ samples for $40 \mathrm{~min}$ with argon (Ar) at a flow rate of $250 \mathrm{~mL} \mathrm{~min}^{-1}$ 1061 in order to remove DMHg before acidification. Total methylated Hg and MMHg were determined as

1062 volatile MMHg hydride by purge and cryo-trapping gas chromatography and detected as elemental $\mathrm{Hg}$ 1063 vapor by atomic fluorescence spectrometry (AFS). The mercury hydrides (from MMHg and $\mathrm{Hg}^{\mathrm{II}}{ }_{\mathrm{i}}$ ) 1064 were formed with $\mathrm{NaBH}_{4}$, sparged from the sample with helium $(\mathrm{He})\left(250 \mathrm{~mL} \mathrm{~min}{ }^{-1}\right)$, concentrated 1065 and then separated $\left(50 \mathrm{~mL} \mathrm{~min}{ }^{-1}\right)$ by cryogenic chromatography before being converted in $\mathrm{Hg}^{0}$ in a 1066 furnace $\left(800^{\circ} \mathrm{C}\right)$ and detected by the AFS detector. The hydride generation technique was initially 1067 proposed by Filippelli et al. (1992), modified by Tseng et al. (1998), and then improved by Stoichev et 1068 al. (2004) and Cossa et al. (2009). Last authors optimized the method in order to detect sub-picomolar 
1069 levels in seawater by lowering the reagent amount (addition of only $0.6-4.0 \mathrm{~mL}$ of a $\mathrm{NaBH}_{4}$ solution of $1070 \quad 0.5 \%(\mathrm{w} / \mathrm{v})$ to a $30-200 \mathrm{~mL}$ water sample) and using a very stable and sensitive detector with an 1071 absolute DL of $\sim 1$ femtomol of $\mathrm{Hg}$ (AFS detector 2500 model equipped with a mirror-coated quartz 1072 cuvette, Tekran $^{\circledR}$ ). The hydrides are formed within a silanized borosilicate glass reactor (5 \% DMDCS 1073 in toluene), then concentrated at low temperature (in liquid nitrogen) and separated by heating (up to $107490^{\circ} \mathrm{C}$ ) in a silanized borosilicate glass tube of $4 \mathrm{~mm}$ interior diameter and filled with Chromosorb 1075 WAW-DMCS (60/80 mesh impregnated with $15 \%$ OV-3). The vector gas was Hg-free He, purified 1076 by passing through charcoal and gold filters. During this set of analyses, the blank $(<0.01 \mathrm{pmol})$ and 1077 its reproducibility ( $2 \%$ ) allowed DLs (calculated as 3 times the standard deviation of the blank) 1078 ranging from 0.005 to $0.025 \mathrm{pmol} \mathrm{L}^{-1}$ depending on the volume of the sample analyzed, and limits of 1079 quantification (calculated as 10 times the standard deviation of the blank) ranging from 0.015 to 0.075 $1080 \mathrm{pmol} \mathrm{L} \mathrm{L}^{-1}$. The analytical reproducibility varied with time between 6 and $15 \%$. The accuracy was not 1081 directly estimated because no certified reference seawater for MMHg was available. The calibration 1082 was performed using the dilutions of a $1 \mathrm{~g} \mathrm{~L}^{-1}$ stock MMHg solution in isopropanol. The dilutions of 1083 the stock solution were performed in $\mathrm{HCl}\left(0.4 \%\right.$, w/v, Suprapur, Merck $\left.{ }^{\circledR}\right)$ water solution. Three times 1084 a day, $2 \mu \mathrm{L}$ of saturated $\mathrm{Hg}^{0}$ vapor was injected into the chromatographic system through a septum in 1085 order to check the response of the instrument and verify the hydride yields. Details of the analytical 1086 system are given in a technical paper (Cossa et al. 2003).

$1087 \mathrm{MeHgT}_{\mathrm{P}}$ was determined by atomic fluorescence spectrometry after $\mathrm{HNO}_{3}$ (4M, Suprapur, 1088 Merck $^{\circledR}$ ) extraction, ethylation of the MMHg and $\mathrm{Hg}^{{ }^{I}}$, followed by chromatographic separation of the 1089 volatile ethylated compounds according to Liang et al. (1994). The accuracy, reproducibility and DL, 1090 established analyzing a Certified Reference Material from the International Atomic Energy Agency 1091 (IAEA-142, Horvat et al., 1997), were 80-120\% (recovery), $10 \%$ (coefficient of variation) and $4 \mathrm{ng} \mathrm{g}^{-}$ $1092{ }^{1}$ (3 times the standard deviation of the blank).

1093 Dissolved gaseous Hg. For analysis of DGM, $300 \mathrm{~mL}$ of sample was purged for $30 \mathrm{~min}$ with ultra-high 1094 purity nitrogen stripped of $\mathrm{Hg}^{0}$ by passage through Au traps, at a flow rate of $300 \mathrm{~L} \mathrm{~min}^{-1}$,

1095 corresponding to a calculated extraction rate of $78 \%$ (results were corrected for this yield). Volatilized 1096 Hg species were trapped and concentrated on an Au trap (Braman and Johnson, 1974), subsequently 1097 desorbed by pyrolysis and quantified by gas-phase AFS. Dissolved gaseous $\mathrm{Hg}$ net production was 1098 evaluated by incubating unfiltered water samples in an incubator located on the deck of the vessel 1099 exposed to sunlight radiations. Temperature was controlled by continuously pumping sea-surface 1100 water through the incubator using a through-flow system. These ex-situ incubations were performed in 1101 batch experiments during 2 to $12 \mathrm{~h}$ periods under the following conditions: (i) absence of light (FEP 
1102 Teflon bottles, wrapped in Al foil); (ii) presence of light (FEP Teflon bottles). Transparent FEP Teflon

1103 bottles absorbed $2.5 \%$ of total incident radiation according to Amyot et al. (1997). Net DGM

1104 production was estimated without taking into account the possible re-oxidation of $\mathrm{Hg}^{0}$.

1105

1106 SI2. Riverine flux calculations

1107 In the absence of any significant relationship between "dissolved" $\mathrm{HgT}$ and RR water discharge the $\mathrm{HgT}_{\mathrm{F}}$

1108 flux was calculated as the product of weighted average of $\mathrm{Hg}$ concentrations and average discharge

1109 (Meybeck and Ragu, 1996; Gairoard et al. 2012). On the contrary, in the case of particulate Hg, we took

1110 into account the existing $\mathrm{HgT}_{\mathrm{P}}$ dependencies upon hydrological changes (Fig. 3). Rhône river discharge

1111 and the suspended particulate matter concentrations were obtained from the Compagnie Nationale du

1112 Rhône (http://www.cnr.tm.fr/). In these conditions, the HgT discharging from the RR between June 2009

1113 and June 2010 has been calculated to be 85 and $800 \mathrm{~mol}$ as "dissolved" and particulate, respectively.

1114 Considering that during the studied period the Rhône discharge was atypically low, and using the 1115 water and particulate mean discharges calculated on the basis of the last 36 years (Gairoard et al., 2012) 1116 the annual HgT efflux from the Rhône River to the GoL would be close to 2.7 and $0.13 \mathrm{kmol}$ for the 1117 particulate and "dissolved" phases respectively. Assuming average ratios of $\mathrm{MeHg} / \mathrm{HgT}$ of 1.9 and $4.1 \%$

1118 (Table 1 of the main manuscript), the best estimates of the MeHg annual Rhône effluxes is calculated to 1119 be 51 and $5 \mathrm{~mol}$ for particulate and the "dissolved" phases, respectively.

1121 SI3. Modeling the diffusive fluxes

$1122 \mathrm{MeHg}_{\mathrm{F}}$ diffusive fluxes were estimated at the stations A to E benthic boundary layer (BBL) using Fick's 1123 first law (Eq. 1):

$$
J=-\left(\varphi D_{w} / \theta^{2}\right)(\delta C / \delta x)_{\mathrm{BBL}}[1]
$$

1125 Where, $J$ is the flux of the solute with concentration $C$ at depth $x, \varphi$ is the sediment porosity (Eq. 2), $\theta$ is

1126 the tortuosity (Eq. 3), and $D_{w}$ is the molecular diffusion coefficient of the solute in seawater. Measuring

1127 porosity, the tortuosity was approached using Boudreau's formulation:

1128

$\varphi=$ pore water volume / (solid volume + pore water volume) [2]

1129

$$
\theta^{2}=1-\ln \left(\varphi^{2}\right)[3]
$$


The $D w$ for $\mathrm{MeHg}_{\mathrm{F}}$ as $\mathrm{MeHgCl}$ were determined coupling the linear regressions of the infinite

1131 dilution diffusion for cations and anions against temperature (Boudreau, 1996) with the infinite-dilution

1132 diffusion for ion pairs (Applin and Lasaga, 1984). The expression was calculated for temperature salinity

1133 and pressure from an empirical equation developed by Kukulka et al. (1987). The adjustment for pore

1134 water viscosity of normal seawater was small at no more than 7 \% (Li and Gregory, 1974). The respective

1135 approximations for $\mathrm{MeHg}_{\mathrm{F}}$ at $\mathrm{T}=18^{\circ} \mathrm{C}, \mathrm{S}=35$ and $\mathrm{P}=2$ bar were $1.84 \times 10^{-5}$ and $8.65 \times 10^{-6} \mathrm{~cm}^{2} \mathrm{~s}^{-1}$.

Table: $\mathrm{MeHgT}_{\mathrm{F}}$ diffusive fluxes from shelf sediments in the Gulf of Lions (Northwestern Mediterranean). The $\mathrm{MeHg}$ gradient at the sediment-water interface is estimated using the difference between $\mathrm{MeHg}$ concentrations in surface sediment pore waters $(2 \mathrm{~cm}$ below the interface $)$ and bottom waters $(10 \mathrm{~cm}$ above the water sediment interface).

\begin{tabular}{|c|c|c|}
\hline Station & $\begin{array}{c}\operatorname{MeHgT}_{\mathrm{F}}\left(\mathrm{pmol} \mathrm{m}^{2} \mathrm{day}^{-1}\right) \\
\text { Flux }\end{array}$ & $\begin{array}{c}\operatorname{MeHgT}_{\mathrm{F}}\left(\mathrm{pmol} \mathrm{L}^{-1}\right) \\
\text { Diff } \text { Pore water and Bottom water }\end{array}$ \\
\hline A-04 & 0.20 & 0.049 \\
\hline B-05 & 1.04 & 0.26 \\
\hline C- 05 & 2.58 & 0.644 \\
\hline D-06 & 0.86 & 0.214 \\
\hline E-03 & 0.88 & 0.219 \\
\hline E-08 & 0.87 & 0.218 \\
\hline
\end{tabular}

\section{References for SI1-3}

1144 Applin, K.R. and A.C. Lasaga. 1984. The determination of SO42-, NaSO4-, and MgSO4 tracer diffusion

1145 coefficients and their application to diagenetic flux calculations. Geochim. Cosmochim. Acta, 48:

$1146 \quad 2151-2162$.

1147 Barnett P.R.O., Watson J. and Connelly D. (1984) A multiple corer for taking virtually undisturbed 1148 samples from shelf, bathyal and abyssal sediments. Oceanol. Acta, 7, 399-408.

1149 Black F. J., Conaway C. H. and Flegal A. R. (2009) Stability of Dimethyl Mercury in Seawater and 1150 Its Conversion to Monomethyl Mercury. Environ. Sci. Technol., 43, 4056-4062.

1151 Bloom N. S. and Crecelius E. A. (1983) Determination of mercury in seawater at sub-nanogram per 1152 liter levels. Mar. Chem., 14, 49-59. 
1153 Boudreau, B.P. 1996. Diffusive tortuosity on fine-grained unlithified sediments. Geochim. Cosmochim. 1154 Acta, 60: 3139-3142.

1155 Braman R. S. and Johnson D. L. (1974) Selective Absorption Tubes and Emission Technique for 1156 Determination of Ambient Forms of Mercury in Air. Environ Sci. Technol., 8, 996-1003.

1157 Cossa D., Averty B., Breaudeau J. and Senard A.-S. (2003) Spéciation du mercure dissous dans les 1158 eaux marines. Analytical methods for the marine environments. Ifremer and French Ministry for 1159 Ecology and Sustainable Development publication MA0303.

1160 Cossa D., Averty B. and Pirrone N. (2009) The origin of methylmercury in open Mediterranean $1161 \quad$ waters. Limnol. Oceanogr., 54, 837-844.

1162 Filippelli M., Baldi F., Brinckman F. E. and Olson G. J. (1992) Methylmercury Determination as 1163 Volatlle Methylmercury Hydride by Purge and Trap Gas Chromatography in Line with Fourier 1164 Transform Infrared Spectroscopy. Environ. Sci. Technol., 26, 1457-1460.

1165 Gairoard, S., O. Radakovitch, F. Eyrolle, W. Ludwig and D. Cossa. 2012. Flux de matière solides et 1166 liquides des bassins versants français à la Méditerranée. Rapport IRSN, CEREGE, UPVD, IFREMER à 1167 l'AERMC, Septembre 2012.87 pages.

1168 Gill G. A. and Fitzgerald W. F. (1988) Vertical mercury distribution in the oceans. Geochim. 1169 Cosmochim. Acta, 52, 1719-1728.

1170 Guédron S., Huguet L., Vignati D. A. L., Liu B., Gimbert F., Ferrarin B. J. D., Zonta R.and Dominik J. 1171 (2012) Tidal cycling of mercury and methylmercury between sediments and water column in the 1172 Venice Lagoon (Italy). Mar. Chem., 130-131, 1-11.

1173 Horvat M., Lupsina V. and Pihlar B. (1991) Determination of total mercury in coal fly ash by gold 1174 amalgamation cold vapour atomic absorption spectrometry. Anal. Chim. Acta, 243, 71-79.

1175 Kukulka, D.J., B. Gebhart and J.C. Mollendorf. 1987. Thermodynamic and transport properties of pure 1176 and saline water. Advanced Heat Transfer, 18: 325-363.

1177 Li, Y.-H. and S. Gregory. 1974. Diffusion of ions in seawater and in deep-sea sediments. Geochim. 1178 Cosmochim. Acta, 38: 703-714.

1179 Liang L., Horvat M. and Bloom N. S. (1994) An improved speciation method for mercury by 1180 GC/CVAFS after aqueous phase ethylation and room temperature precollection. Talanta, 41, 3711181379. 
1182 Mason R. P. (1991) The chemistry of mercury in the equatorial Pacific Ocean. PhD Thesis. University 1183 of Connecticut, USA, 305 pp.

1184 Mason R. P. and Fitzgerald W. F. (1993) The distribution and biogeochemistry cycling of mercury in 1185 the Equatorial Pacific Ocean. Deep-Sea Res. I, 40, 1897-1924.

1186 Meybeck, M. and A. Ragu. 1996. River discharges to the oceans: an assessment of suspended solids, 1187 major ions and nutrients. Division Environment, Information and Assessment (Water Branch) Report, 1188 UNEP, Nairobi, 256 pp.

1189 Stoichev T. R., Rodriguez Martin-Doimeadios C., Tessier E., Amouroux D. and Donard O. F. X.

1190 (2004) Improvement of analytical performances for mercury speciation by on-line derivatization, 1191 cryofocussing and atomic fluorescence spectrometry. Talanta, 62, 433-438.

1192 Tseng C. M., de Diego A., Pinaly H., Amouroux D. and Donard O. F. X. (1998) Cryofocusing 1193 coupled to atomic absorption spectrometry for rapid and simple mercury speciation in 1194 environmental matrices. J. Anal. At. Spectrom., 13, 755-764. 